University of New Hampshire

University of New Hampshire Scholars' Repository

$10-2004$

\title{
A major regional air pollution event in the northeastern United States caused by extensive forest fires in Quebec, Canada
}

\author{
Linsey J. Debell \\ University of New Hampshire - Main Campus \\ Jack E. Dibb \\ University of New Hampshire, jack.dibb@unh.edu \\ R. Talbot \\ University of New Hampshire, robert.talbot@unh.edu \\ J W. Munger \\ Harvard University \\ E V. Fischer \\ Mount Washington Observatory
}

See next page for additional authors

Follow this and additional works at: https://scholars.unh.edu/earthsci_facpub

Part of the Atmospheric Sciences Commons

\section{Recommended Citation}

DeBell, L. J., R. W. Talbot, J. E. Dibb, J. W. Munger, E. V. Fischer, and S. E. Frolking (2004), A major regional air pollution event in the northeastern United States caused by extensive forest fires in Quebec, Canada, J. Geophys. Res., 109, D19305, doi:10.1029/2004JD004840.

This Article is brought to you for free and open access by the Earth Sciences at University of New Hampshire Scholars' Repository. It has been accepted for inclusion in Earth Sciences Scholarship by an authorized administrator of University of New Hampshire Scholars' Repository. For more information, please contact Scholarly.Communication@unh.edu. 


\section{Authors}

Linsey J. Debell, Jack E. Dibb, R. Talbot, J W. Munger, E V. Fischer, and Steve Frolking 


\title{
A major regional air pollution event in the northeastern United States caused by extensive forest fires in Quebec, Canada
}

\author{
Linsey J. DeBell, ${ }^{1}$ Robert W. Talbot, and Jack E. Dibb \\ Institute for the Study of Earth, Oceans, and Space, University of New Hampshire, Durham, New Hampshire, USA
}

\author{
J. William Munger \\ Department of Earth and Planetary Sciences, Harvard University, Cambridge, Massachusetts, USA
}

Emily V. Fischer and Steve E. Frolking

Institute for the Study of Earth, Oceans, and Space, University of New Hampshire, Durham, New Hampshire, USA

Received 31 March 2004; revised 2 July 2004; accepted 15 July 2004; published 6 October 2004.

[1] During early July 2002, wildfires burned $\sim 1 \times 10^{6}$ ha of forest in Quebec, Canada. The resultant smoke plume was seen in satellite images blanketing the U.S. east coast. Concurrently, extremely high $\mathrm{CO}$ mixing ratios were observed at the Atmospheric Investigation, Regional Modeling, Analysis and Prediction (AIRMAP) network sites in New Hampshire and at the Harvard Forest Environmental Measurement Site (HFEMS) in Massachusetts. The CO enhancements were on the order of 525-1025 ppbv above low mixing ratio conditions on surrounding days. A biomass burning source for the event was confirmed by concomitant enhancements in aerosol $\mathrm{K}^{+}, \mathrm{NH}_{4}^{+}, \mathrm{NO}_{3}^{-}$, and $\mathrm{C}_{2} \mathrm{O}_{4}^{2-}$ mixing ratios at the AIRMAP sites. Additional data for aerosol $\mathrm{K}$, organic carbon, and elemental carbon from the Interagency Monitoring of Protected Visual Environments network and CO data from Environmental Protection Agency sites indicated that the smoke plume impacted much of the U.S. east coast, from Maine to Virginia. CO mixing ratios and $\mathrm{K}$ concentrations at stations with 10-year or longer records suggested that this was the largest biomass burning plume to impact the U.S. east coast in over a decade. Furthermore, $\mathrm{CO}$ mixing ratios and aerosol particles with diameters $<2.5 \mu \mathrm{m}\left(\mathrm{PM}_{2.5}\right)$ mass and scattering coefficients from the AIRMAP network and HFEMS indicated that this event was comparable to the large anthropogenic combustion and haze events which intermittently impact rural New England. The degree of enhancement of $\mathrm{O}_{3}, \mathrm{NO}_{y}$, $\mathrm{NO}_{3}^{-}, \mathrm{NH}_{4}^{+}$, and $\mathrm{SO}_{4}^{2-}$ in the biomass plume showed significant variation with elevation and latitude that is attributed to variations in transport and surface depositional processes. INDEX TERMS: 0305 Atmospheric Composition and Structure: Aerosols and particles (0345, 4801); 0315 Atmospheric Composition and Structure: Biosphere/atmosphere interactions; 0322 Atmospheric Composition and Structure: Constituent sources and sinks; 0345 Atmospheric Composition and Structure: Pollution - urban and regional (0305); 0368 Atmospheric Composition and Structure: Troposphere - constituent transport and chemistry; KEYWORDS: biomass burning, aerosols

Citation: DeBell, L. J., R. W. Talbot, J. E. Dibb, J. W. Munger, E. V. Fischer, and S. E. Frolking (2004), A major regional air pollution event in the northeastern United States caused by extensive forest fires in Quebec, Canada, J. Geophys. Res., 109, D19305, doi:10.1029/2004JD004840.

\section{Introduction}

[2] Biomass burning has significant regional and global impacts on tropospheric chemistry [Andreae and Merlet,

\footnotetext{
${ }^{1}$ Now at Cooperative Institute for Research in the Atmosphere, Colorado State University, Fort Collins, Colorado, USA.

Copyright 2004 by the American Geophysical Union. 0148-0227/04/2004JD004840
}

2001]. Models indicate that biomass burning contributes $15-30 \%$ of the CO [Galanter et al., 2000; Intergovernmental Panel on Climate Change (IPCC), 2001], 9\% of the $\mathrm{O}_{3}$ [Marufu et al., 2000], and 14-18\% of the $\mathrm{NO}_{x}$ $[I P C C, 2001]$ to the global tropospheric source of these species. On a global basis, biomass burning is the dominant source of organic carbon (OC) aerosol, being approximately twice the emissions from fossil fuel. It is also a source of black carbon (BC) aerosol that is comparable to that from the burning of fossil fuels 
[IPCC, 2001]. Biomass burning also impacts the global radiation budget through the release of important greenhouse gases and, regionally, through the emission of both scattering and absorbing aerosols [IPCC, 2001].

[3] The large amount of primary and secondary aerosols, $\mathrm{O}_{3}$, and $\mathrm{O}_{3}$ precursors present in forest fire smoke plumes impacts background levels of those species and can also result in significant haze events locally, or more rarely, on a regional scale [Crutzen and Andreae, 1990; Conard and Ivanova, 1997; Nichol, 1998; Forster et al., 2001; Khalil and Rasmussen, 2003; Cooper et al., 2001]. On a regional scale, models indicate that biomass burning in Canada, primarily forest fires in summer, can contribute up to $60 \%$ of the $\mathrm{CO}, 45 \%$ of the $\mathrm{NO}_{X}$, and $20 \%$ of the $\mathrm{O}_{3}$ background tropospheric burden in this area of North America [Galanter et al., 2000]. A detailed study on the origin of tropospheric $\mathrm{O}_{3}$ in Canada indicated that photochemical $\mathrm{O}_{3}$ production within biomass smoke plumes makes a negligible direct contribution to the $\mathrm{O}_{3}$ budget $(\sim 2 \%)$. However, biomass fires can increase regional $\mathrm{O}_{3}$ levels through increased background levels of $\mathrm{NO}_{x}$ [Mauzerall et al., 1996]. Modeling studies of a Canadian forest fire event indicate that they can also affect $\mathrm{CO}$ and $\mathrm{O}_{3}$ mixing ratios on the U.S. east coast with local enhancements of up to $\sim 250$ and $\sim 30 \mathrm{ppbv}$, respectively [McKeen et al., 2002; Wotawa and Trainer, 2000].

[4] During the first week of July, there was widespread fire in northern Quebec, Canada (Figure 1) (T. Johnston, Canadian Interagency Forest Fire Centre (CIFFC), CIFFC Canada Report 2002, report available by request, http:// www.ciffc.ca/). This fire outbreak ultimately burned $1,012,785$ ha, the largest reported burn area in Quebec since 1989. To put this event in perspective, over the 10 years prior to this event, reported annual totals for burn area in Quebec have ranged from 27,112 to 727,727 ha with an average value of 267,212 ha. The smoke plume produced from these fires resulted in a regionalscale haze event, impacting both Canada and much of the U.S. east coast. The smoke plume was captured by air quality monitoring sites operated by the Atmospheric Investigation, Regional Modeling, Analysis and Prediction (AIRMAP) network, the Harvard Forest Environmental Measurement Site (HFEMS), the Interagency Monitoring of Protected Visual Environments (IMPROVE) network, and the Environmental Protection Agency (EPA). Here we present a chemical characterization of the smoke plume and document its geographical extent and impact on atmospheric chemistry in the northeastern United States.

\section{Methods}

\subsection{AIRMAP Network}

[5] The AIRMAP program operates several atmospheric chemistry monitoring sites in New Hampshire, including Thompson Farm (TF), Castle Springs (CS), and Mount Washington (MWO) (Figure 1). Each site is equipped for continuous measurements of an extensive suite of gas phase species, aerosol chemical, physical, and optical properties, and meteorological parameters. All sites are equipped with Teflon lined sampling manifolds with inlet heights varying from 12 to $15 \mathrm{~m}$ above ground level. In addition, 24-hour aerosol samples are collected on Teflon filters for chemical analysis [DeBell et al., 2004]. Measurements included $\mathrm{CO}, \mathrm{O}_{3}, \mathrm{NO}_{y}$, aerosol scattering, aerosol mass, aerosol condensation nuclei, and aerosol soluble ions. See Appendix A for detailed methods information for the AIRMAP network.

\subsection{Harvard Forest Environmental Measurement Site}

[6] HFEMS is located at Harvard Forest in Petersham, Massachusetts (Figure 1). Various gas concentrations are measured from a $30-\mathrm{m}$ tower $\sim 6 \mathrm{~m}$ above the surrounding forest canopy. Carbon monoxide is measured using a modified infrared absorbance gas filter correlation analyzer. The sample stream is dried to a dewpoint of less than $-20^{\circ} \mathrm{C}$ in a cold trap to eliminate water vapor interference. The instrument zero is determined by removal of $\mathrm{CO}$ from the ambient air using Sofnocat (Molecular Products Limited, Essex, United Kingdom). The analyzer is calibrated using 500-ppbv absolute standards (Scott Marrin, Inc.) that are referenced to a set of archival standards that are traceable to Climate Monitoring and Diagnostics Laboratory standards [Novelli et al., 1998]. Ozone mixing ratios are measured using a UV absorbance photometer (Thermo Environmental Instruments, Franklin, Massachusetts) configured to sequentially sample from eight inlet heights through the forest canopy and a fast-response $\mathrm{C}_{2} \mathrm{H}_{4}$ chemiluminescence analyzer that only samples from $29 \mathrm{~m}$. Calibration of the fast-response instrument is made by comparison to measurements made by the profile instrument at the same inlet height. The UV absorbance instrument is calibrated against a dedicated $\mathrm{O}_{3}$ calibration source (Dasibi 1008PC). $\mathrm{NO}_{y}$ is determined by catalytic conversion on a hot gold catalyst situated at the inlet, coupled with a fast response chemiluminescence analyzer. The analyzer is calibrated by addition of $\mathrm{NO}$ and $\mathrm{NO}_{2}$ standards at the catalyst inlet [Munger et al., 1996].

\subsection{EPA Monitoring Stations}

[7] Hourly $\mathrm{O}_{3}$ and $\mathrm{CO}$ data from state or local air monitoring stations were retrieved from the Atmospheric Infrared Sounder database. Sites were chosen for inclusion in this paper on the basis of geographical location and the presence of both $\mathrm{CO}$ and $\mathrm{O}_{3}$ monitors (Figure 1), and they are not exclusively rural. It should be noted that these monitoring stations are operated for compliance rather than research reasons, so the precision and accuracy of the data, particularly at lower mixing ratios, vary from site to site. We thus limit use of these data to documenting the geographic extent and timing of the plume as it moved across the eastern United States.

\subsection{IMPROVE Network}

[8] Data were taken from 23 IMPROVE network aerosol samplers operated on the east coast of the United States during the summer of 2002 (Figure 1). Unlike the AIRMAP stations which collect bulk samples the IMPROVE network aerosol collectors have cyclone separators in front of the filters which only allow particles with diameters $<2.5 \mu \mathrm{m}$ to pass through, referred to as $\mathrm{PM}_{2.5}$ aerosol. Details of the standard IMPROVE 


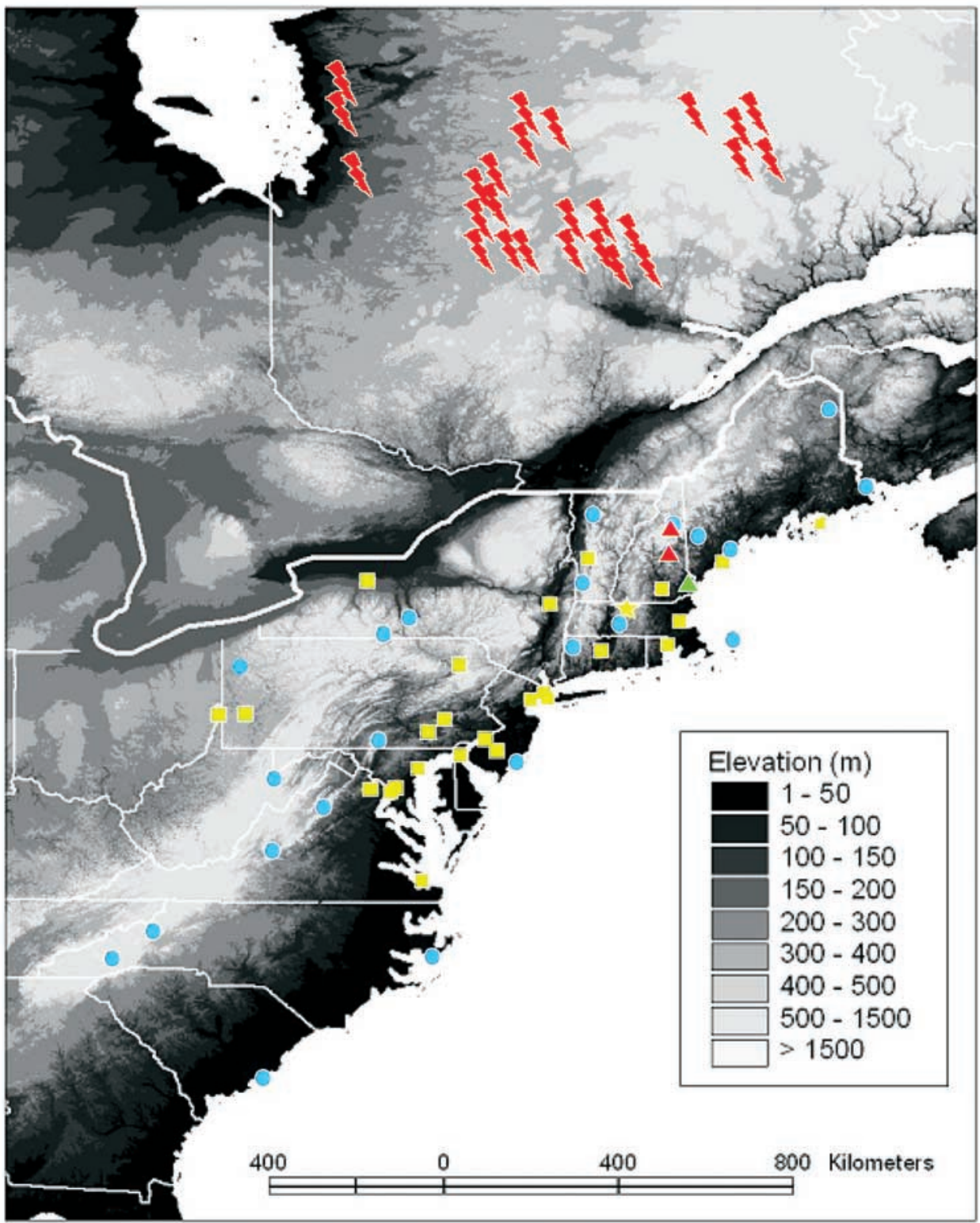

Figure 1. The approximate fire locations on 6 July 2002 for Canada are shown by red flags (locations are taken from Canadian Forest Service, Canadian Wildland Fire Information System at http:// cwfis.cfs.nrcan.gc.ca/en/index_e.php). Quebec was the only region experiencing significant biomass burning. The monitoring sites from all four networks are shown: AIRMAP, triangles; HFEMS, star; IMPROVE, circles; and the EPA, squares. The color coding represents the types of measurements conducted at that site which are used in this study. Blue indicates aerosol chemical and physical measurements, yellow indicates gas phase measurements, red indicates gas phase and aerosol chemical and physical measurements, and green indicates gas phase and aerosol physical and optical measurements. The digital elevation source is GTOPO30 (http://edcdaac.usgs.gov/gtopo30/gtopo30.asp).

aerosol sampling system, protocols, and analysis techniques are provided by Eldred et al. [1990] and Malm et al. [1994, 1996]. Briefly, the aerosol samplers were operated every 3 days for a 24-hour period from midnight to midnight local time. $\mathrm{PM}_{2.5}$ samples were collected on 25-mm stretched Teflon mesh filters with $3.0-\mu \mathrm{m}$ pore size and a rigid olefin ring support. Filters were measured gravimetrically and analyzed by X-ray fluorescence to provide measurements of particle mass and elemental composition. $\mathrm{PM}_{10}$ filters were also collected for gravi- metric determination of the mass of particles $<10 \mu$ in diameter.

\section{July 2002 Smoke Plume Event}

\subsection{July Fires in Quebec}

[9] Of the over $1 \times 10^{6}$ ha burned, 780,745 were north of $52^{\circ} \mathrm{N}$ in the relatively unprotected extensive zone (Figure 1) (T. Johnston, Canadian Interagency Forest Fire Centre, CIFFC Canada Report 2002, report available by request, 
a)
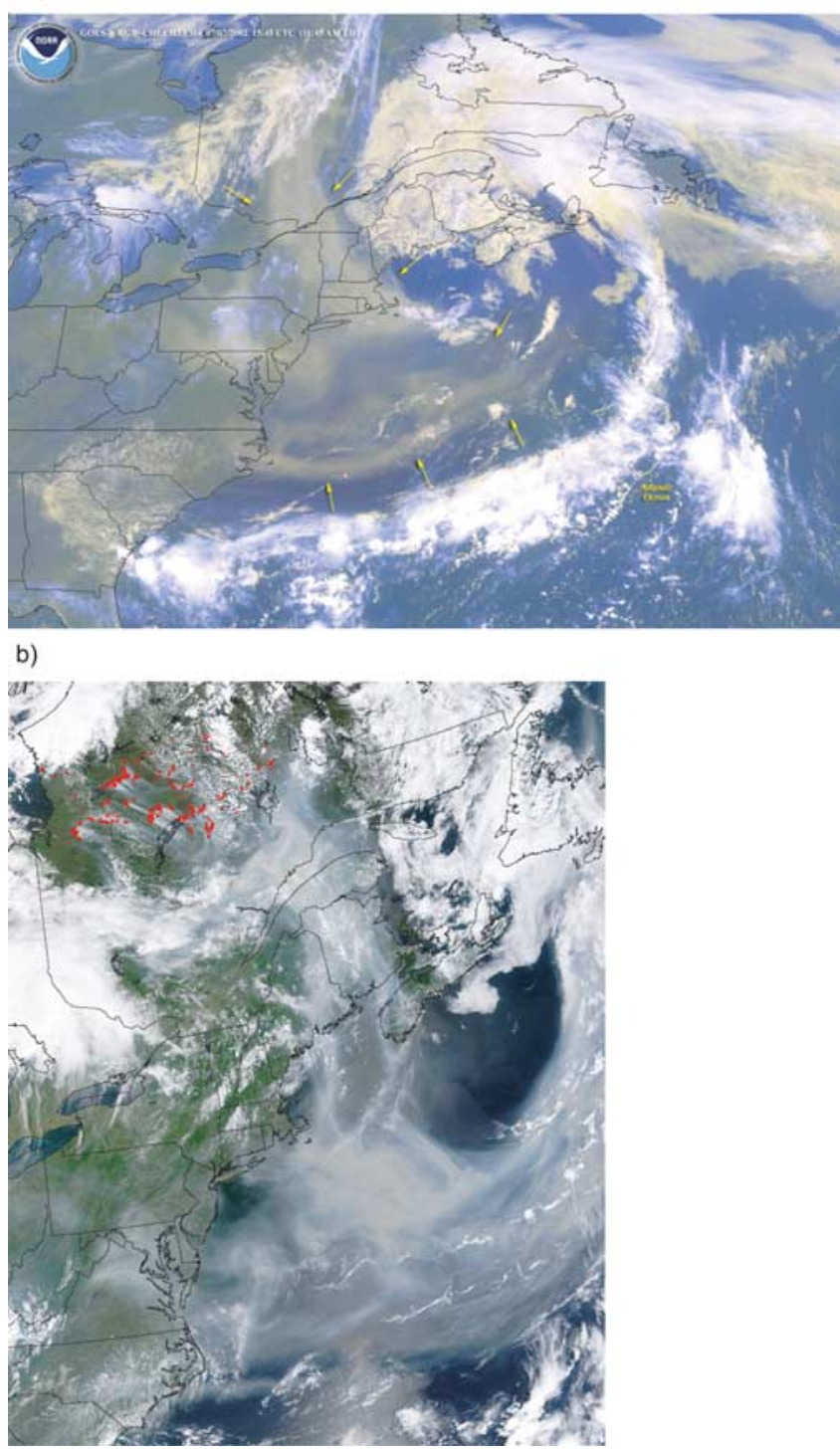

Figure 2. The dramatic shift in the plumes transport path from 7 July to 8 July reflects a shift in geostrophic flow. (a) The Geostationary Operational Environmental Satellite (GOES) image was retrieved from the Operational Significant Event Imagery (OSEI) archive (http://www.osei. noaa.gov) and is credited to National Oceanic and Atmospheric Administration (NOAA). (b) The Moderate Resolution Imaging Spectroradiometer (MODIS) image was retrieved from the NASA Visible Earth directory (http:// visibleearth.nasa.gov/) and is credited to Jacques Descloitres, MODIS Land Rapid Response Team, NASA/Goddard Space Flight Center.

http://www.ciffc.ca/). The area burned consisted of continuous (50-100\% forest covered) and discontinuous $(<50 \%$ forest covered) softwood forest classified as being either in the Taiga or Boreal Shield ecozones (Natural Resources Canada, http://www.cfl.scf.rncan.gc.ca/ecosys/classif/intro eco e.htm). The areas burned may also have had significant soil carbon content, in some cases up to those levels defined as being peatlands (Climate Change Impacts and Adapta- tion, Sensitivities to Climate Change in Canada, available at http://adaptation.nrcan.gc.ca/app/imagerepository/ 73F994F92D004001ADD18A9F11F2E3B3.gif).

[10] The area of smoke recorded nationally in Canada peaked on 6 July at over $213,000 \mathrm{~km}^{2}$, its highest level for 2002 (Canadian Forest Service, National Forest Fire Situation Report, http://www.nrcan-rncan.gc.ca/cfs-scf/science/ prodserv/firereport/archives_e.php?year $=2002 \&$ month $=$ $07 \&$ day=10). On 7-8 July 2002, a huge smoke plume was seen blanketing much of the U.S. east coast in Geostationary Operational Environmental Satellite (GOES) and Moderate Resolution Imaging Spectroradiometer images (Figure 2). This plume was clearly the same smoke plume seen on 6 July in Canada from the large forest fires burning in the Quebec region.

\subsection{Plume Transport to New England}

[11] The smoke plume was transported from the north in a subsiding air mass along the western edge of a low-pressure system. Hybrid Single-Particle Lagrangian Integrated Trajectory (HY-SPLIT) backward trajectories were calculated with end points at MWO; TF; Acadia, Maine; and Washington, D. C., using Eta Data Assimilation System meteorological data and both model vertical velocity and isentropic versions of vertical motion calculations $(R$. R. Draxler and G. D. Rolph, HY-SPLIT model is available at the NOAA ARL READY Web site at http://www.arl.noaa. gov/ready/hysplit4.html; G. D. Rolph, data is available at Real-time Environmental Applications and Display System (READY) Web site at http://www.arl.noaa.gov/ready/ hysplit4.html). Trajectories with start times corresponding to peak $\mathrm{CO}$ mixing ratios were run for 500,800 , and $1000 \mathrm{~m}$ above ground level for all sites except MWO, where they were run at 1800, 2000, and $2500 \mathrm{~m}$ above sea level. Trajectories indicated that transport times from northern Quebec ranged from $\sim 1$ day to $\mathrm{MWO}$ to $\sim 3$ days to Washington, D. C. (not shown).

[12] The upper level low-pressure system, which was present at $500 \mathrm{hPa}$ on 7 July 0000 UT over New Brunswick (not shown), controlled the transport path of the smoke plume. North winds associated with the western side of the cyclone transported the smoke plume directly southward from Quebec (Figure 3). On 7 July the plume can be seen in GOES images in a fairly concentrated band covering parts of New Hampshire, Vermont, and New York (Figure 2a). The plume was diffuse, but patchy, over most of the eastern seaboard down to the Washington, D. C., area. By 8 July 0000 UT the low had moved further northeast, changing the transport direction of the smoke plume out of Quebec (Figure 3). On 8 July the smoke plume was moving more southeasterly and was being transported over Maine and out over the Atlantic (Figure 3). The plume also appeared to be pulled back inland near Virginia (Figure 2b). By 9 July 0000 UT the pressure system was no longer impacting the U.S. east coast, and the $850-\mathrm{hPa}$ streamlines indicated westerly winds with no direct transport from the Quebec region (Figure 3). Below we show that surface chemical observations provide strong support for the variation of transport paths inferred from satellite imagery and synoptic analyses.

[13] The transport path of an air mass is often highly dependent on the transport altitude, so an estimate of the 
a)

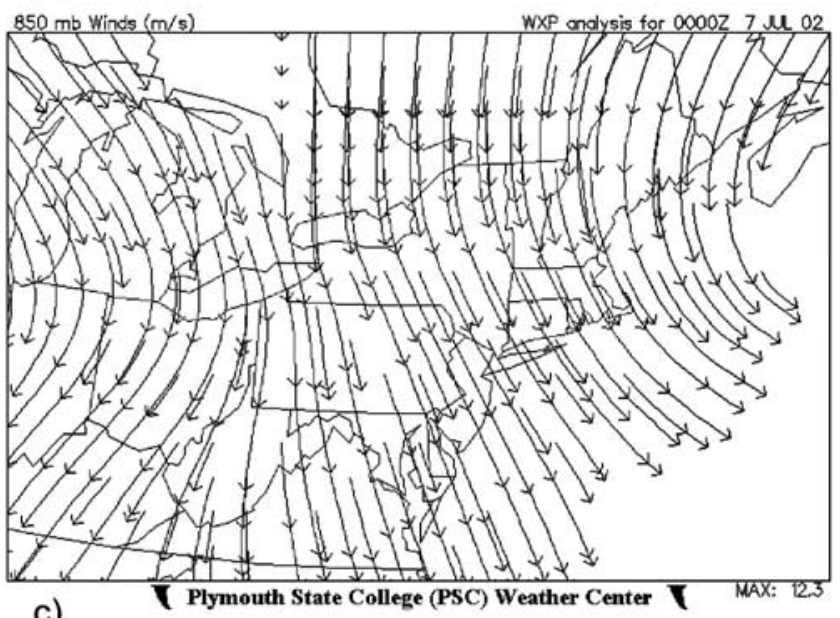

c)

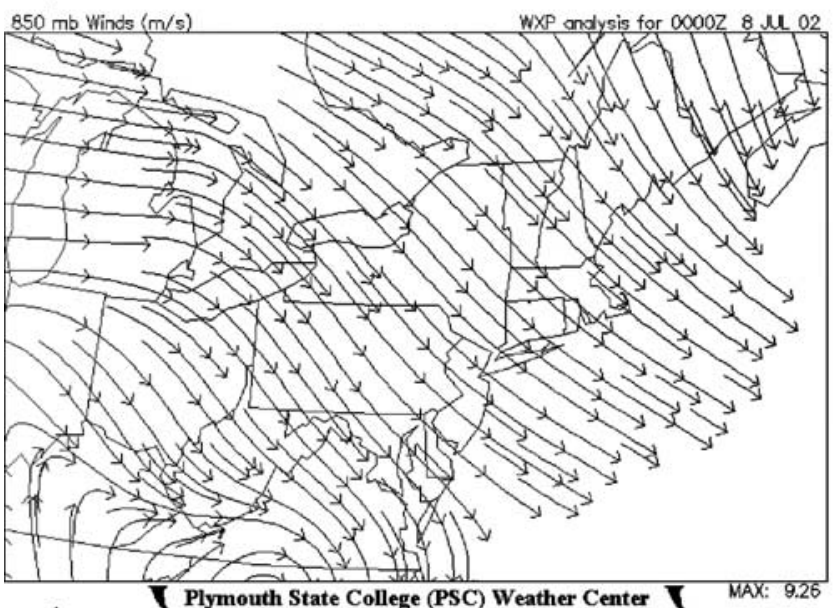

e)

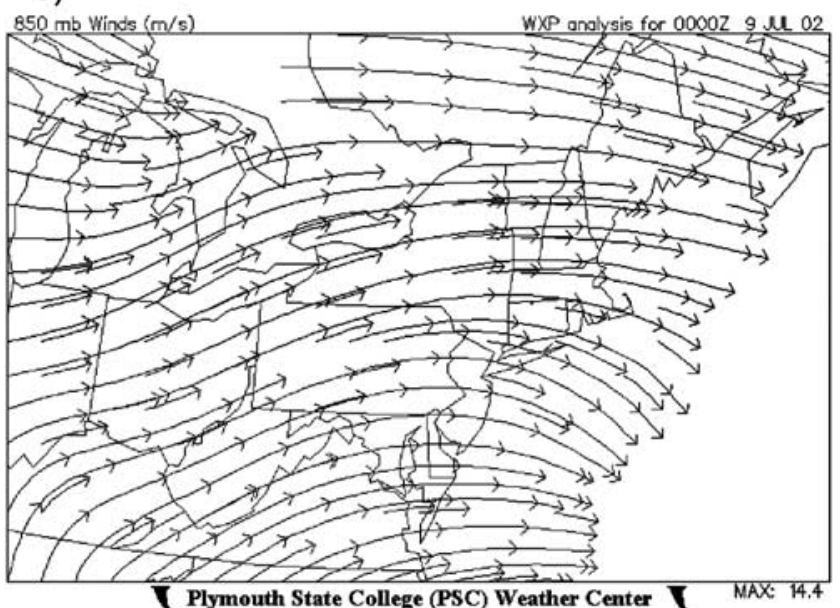

b)

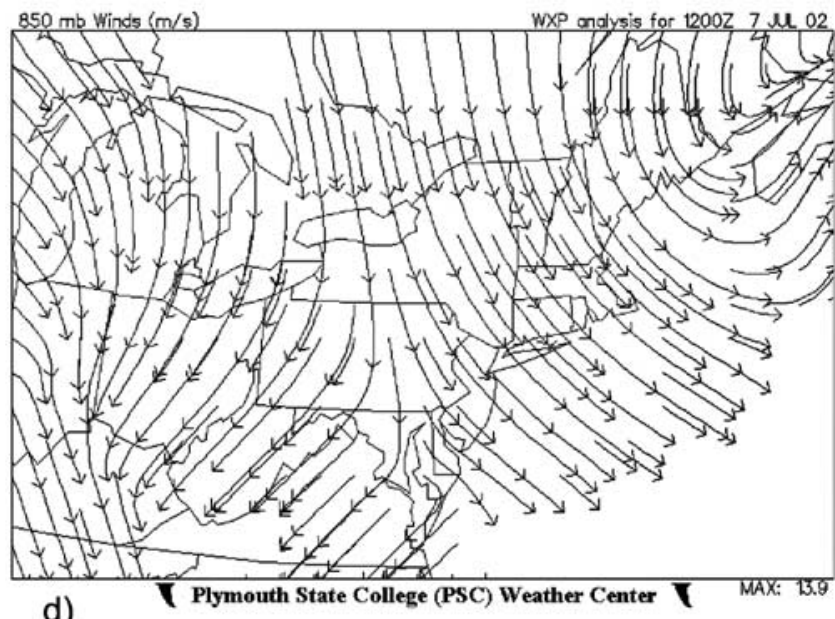

d)

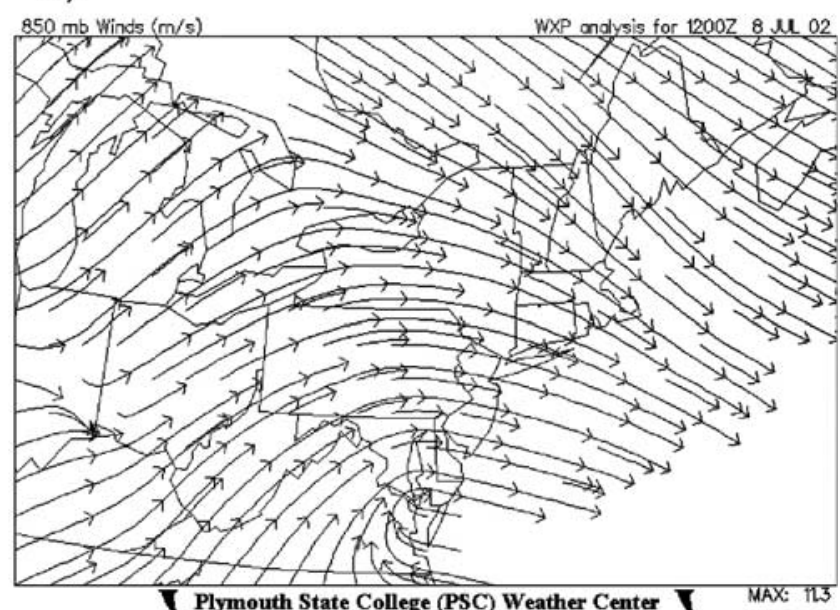

Figure 3. The 850-hPa streamlines show the transport path of the smoke plume from Quebec from 0000 UT 7 July to 0000 UT 9 July.

emission height of the smoke plume is critical for understanding the transport history of the smoke plume. Large fires that burn up into the forest canopy are often intense enough to generate smoke/convection plumes that routinely reach well up into the troposphere and, on occasion, penetrate the tropopause [Cofer et al., 1996]. Ground fires or smoldering peatlands are cooler and do not generate convective lifting that is as intense. Previous modeling efforts have assumed emissions occurred throughout the lower to middle troposphere either in the first 1.5-4.5 [McKeen et al., 2002] or in the first $0.5-3 \mathrm{~km}$ [Wotawa and Trainer, 2000] of the atmosphere. McKeen et al. [2002] found that their modeled smoke plume transport from Canadian fires in 1995 to the east coast of the United States 
a)

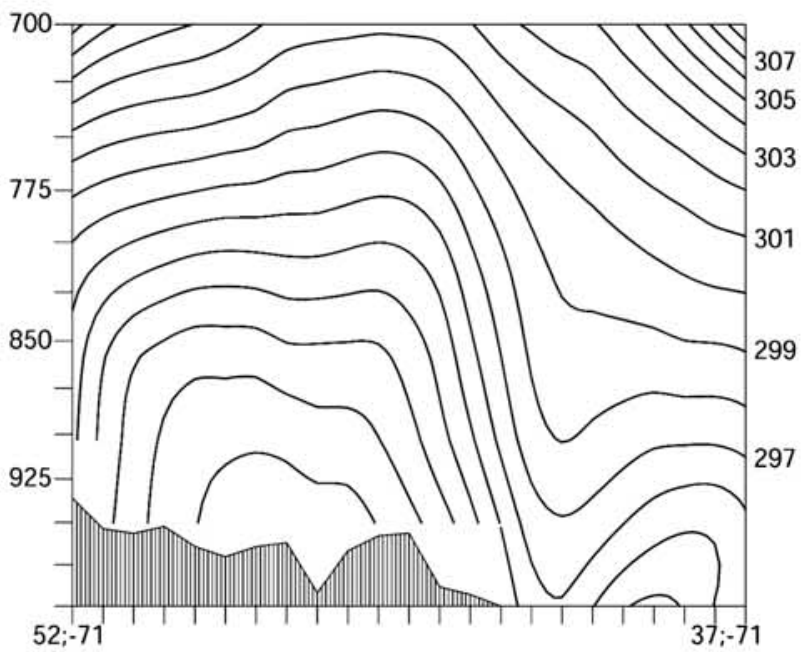

0000 UTC 7 July Potential Temp. (K)

b)

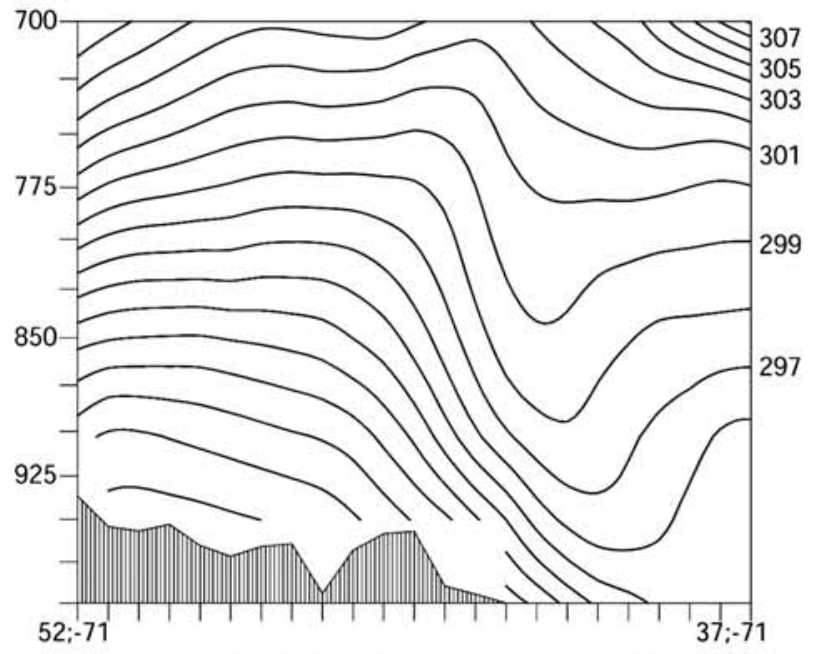

c)

1200 UTC 7 July, Potential Temp. (K)

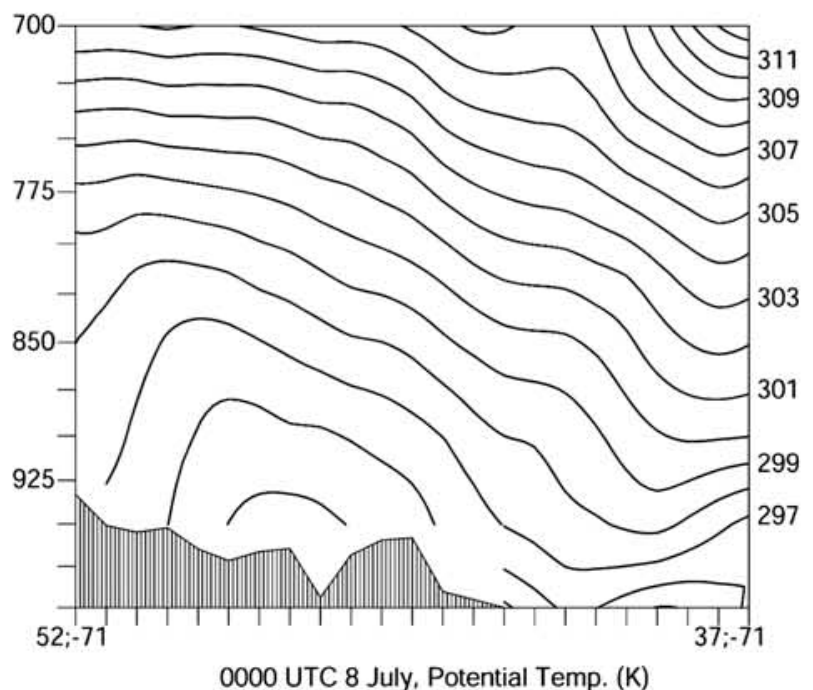

0000 UTC 8 July, Potential Temp. (K) was fairly insensitive to height, within the $1.5-4.5 \mathrm{~km}$ range, owing to the relatively strong subsidence associated with the event. On the basis of these prior studies and the magnitude of the July 2002 fires in Quebec we assume that the plume probably had several effective emission heights leading to southerly advection out of the region between the surface and the $3-$ to $5-\mathrm{km}$ altitude range.

[14] The air mass containing the plume was relatively free of precipitation, based on surface observations reporting mainly clear skies (http://vortex.plymouth.edu/). Therefore, aside from turbulent near-surface flow resulting from the underlying terrain and thermal convection, we can assume an approximately adiabatic atmosphere, with air parcels following isentropic surfaces. North-to-south cross sections of isentropic surfaces taken along the approximate longitude of MWO show that transport height in the lower troposphere $(<3 \mathrm{~km})$ decreased with increased transport time during the period of this event (Figures $4 \mathrm{a}, 4 \mathrm{~b}$, and $4 \mathrm{c}$ ). This effect weakened between 7 July 0000 and 8 July 0000 UT as the cold front moved further offshore. On the basis of the isentropic surfaces, all smoke injected into the bottom $1500 \mathrm{~m}$ of the atmosphere would have had significant interaction with the surface by the time it reached $42^{\circ} \mathrm{N}$ latitude. In addition, all isentropic surfaces below $3 \mathrm{~km}$ exhibited strong subsidence, suggesting that much of the smoke emitted into the lower troposphere was eventually transported into the boundary layer. Both isentropic and model vertical velocity trajectories support transport in the surface layer as the Quebec smoke plume traveled to TF and Washington, D. C. (not shown).

\section{New England Air Chemistry Observations} 4.1. Gas Phase Observations

[15] Extremely high $\mathrm{CO}$ mixing ratios were measured at all three AIRMAP network sites and the HFEMS at the same time that the smoke plume was seen on satellite images of the U.S. east coast. At MWO, CS, and TF, 1-min-averaged CO levels peaked at 1437, 830, and $758 \mathrm{ppbv}$ at 0030,0238 , and 0654 LT on 8 July, respectively (Figure 5). The AIRMAP sites are arranged along both a latitudinal and an altitudinal gradient (Figure 1), and $\mathrm{CO}$ mixing ratios clearly decreased with decreasing altitude and latitude. These mixing ratios were significantly elevated for these rural New England sites, and the maximum values observed at MWO and TF were above the 99th percentile of the site-specific, multiyear data sets. At CS this event produced the largest $\mathrm{CO}$ mixing ratios observed to date.

[16] At HFEMS, where $\mathrm{CO}$ has been measured nearly continuously since 1992, this event stands out as one of the most significant events during this time period, with the exception of nocturnal events with nearby domestic heating emissions trapped by shallow inversions. Hourly averaged

Figure 4. Cross sections of the isentropic surfaces were taken from the Eta model forecasts along a north-south cross section from the approximate region of the fires in Quebec down to approximately Washington, D. C., along the approximate longitude of MWO. The surfaces show decreasing transport height with increasing transport time in the first $3 \mathrm{~km}$ of the atmosphere. 


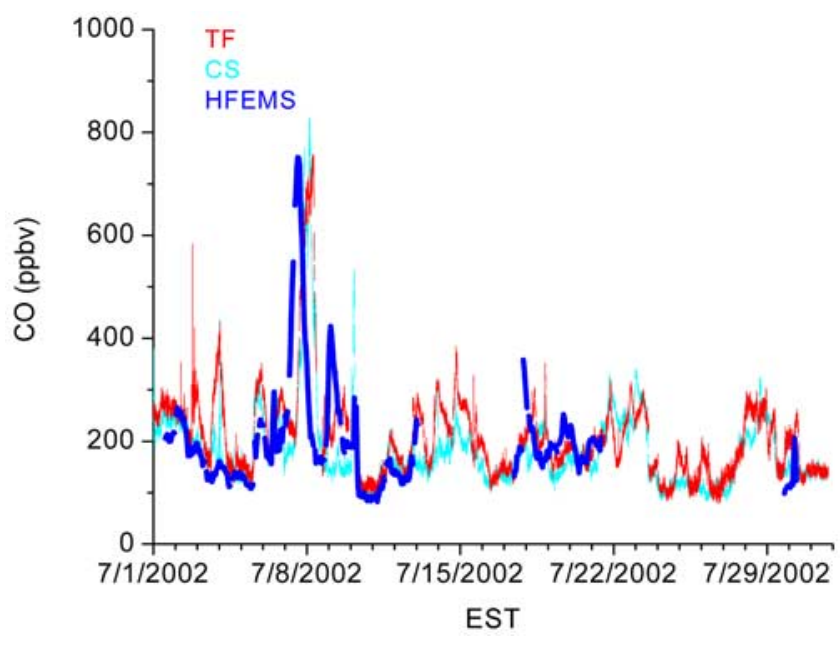

Figure 5. Elevated CO mixing ratios on 7-8 July 2002 clearly stand out compared to the rest of the month. Data from MWO are not shown, as elevated CO levels from the $\mathrm{Cog}$ railway disguise the similarities in regional $\mathrm{CO}$ levels on days surrounding the event. The three sites clearly capture a regional signal on most days.

CO mixing ratios peaked at 752 ppbv on 7 July at 1400 LT (Figure 5). The peak hours of the event were all well above the 95 th percentile ( $323 \mathrm{ppbv}$ ) and included the maximum value for summertime observations over the entire 12 -year data set. The high $\mathrm{CO}$ mixing ratios observed during this event are on the order of $150 \mathrm{ppbv}$ above peak values observed during the previous 12 summers (Figure 6).

[17] Ozone was elevated and positively correlated with $\mathrm{CO}$ at MWO and CS (Figures 7a and 7b). At MWO and CS, $\mathrm{O}_{3}$ peaked at 92 and $44 \mathrm{ppbv}$, respectively. These mixing ratios represent $\mathrm{O}_{3}$ enhancements of approximately 60 and 14 ppbv above low mixing ratios of 35 and $30 \mathrm{ppbv}$ on days surrounding the fire event at MWO and CS, respectively. The enhancement at CS was minimal but significant for showing the transition in plume characteristics with both site elevation and latitude. Standard least squares linear regression of $\mathrm{O}_{3}$ versus CO yielded an $R^{2}$ of 0.52 (slope $=0.028 \mathrm{ppv} p p b v^{-1}$ ) at MWO and 0.44 (slope $=0.014 \mathrm{ppbv} \mathrm{ppbv}^{-1}$ ) at CS. In contrast, $\mathrm{O}_{3}$ was not significantly elevated during the event at HFEMS or TF, the lower elevation and more southern sites (Figures $7 \mathrm{c}$ and $7 \mathrm{~d}$ ). $\mathrm{CO}$ is a good tracer of combustion because it is a primary product of this process, whereas $\mathrm{O}_{3}$ is a secondary product from the precursor species, reactive nitrogen and hydrocarbons, released during the combustion process. The similarity in timing between the $\mathrm{O}_{3}$ and $\mathrm{CO}$ enhancements, shown by the $\mathrm{O}_{3}$ : $\mathrm{CO}$ correlation, suggests that the $\mathrm{O}_{3}$ enhancement is associated with the combustion products.

[18] During the time period of enhanced $\mathrm{CO}, \mathrm{NO}_{y}$ mixing ratios at CS were elevated, reaching $7.9 \mathrm{ppbv}$, and significantly correlated with $\mathrm{CO}\left(R^{2}=0.86\right.$, slope $=0.0074 \mathrm{ppbv}$ $\mathrm{ppbv}^{-1}$ ) (Figure $7 \mathrm{~b}$ ). While $\mathrm{NO}_{y}$ mixing ratios were quite low at HFEMS, peaking at only $3.2 \mathrm{ppbv}$, a positive correlation with CO was again quite strong $\left(R^{2}=0.88\right.$, slope $\left.=0.0025 \mathrm{ppbv}_{\mathrm{ppbv}}{ }^{-1}\right)($ Figure $7 \mathrm{c}) . \mathrm{NO}_{y}$ mixing ratios were comparable at TF ( $\sim 3 \mathrm{ppbv})$ and reasonably correlated with CO $\left(R^{2}=0.51\right.$, slope $=0.0024 \mathrm{ppbv} p \mathrm{pbv}^{-1}$ excluding the last hours of the event after 8 July at 0700 LT) (Figure 7d). The lower correlation at TF is due in part to the strong nocturnal inversion at the site, during which $\mathrm{O}_{3}$ and $\mathrm{NO}_{y}$ (i.e., $\mathrm{HNO}_{3}$ ) are depleted by surface deposition. As the forest fire plume was passing (as evidenced by rapidly decreasing CO mixing ratios), a local pollution plume influenced the TF site with mixing ratios of $\mathrm{CO}, \mathrm{NO}_{y}$, and condensation nuclei $(\mathrm{CN})$ jumping up significantly, obscuring the latter portion of the forest fire event at TF. The $\mathrm{NO}_{y}$ : $\mathrm{CO}$ slopes observed during the fire are distinctly lower then those observed in the overall data sets. For comparison, at TF the correlation of $\mathrm{NO}_{y}$ versus $\mathrm{CO}$ for the overall 2002 data set yielded a slope of 0.12 . $\mathrm{NO}_{y}$ measurements were not conducted at MWO during this event.

\subsection{Aerosol, Chemical, Optical, and Physical Observations}

[19] At all three AIRMAP stations, CN levels were elevated and positively correlated with $\mathrm{CO}$ (Figure 8). At MWO, CS, and TF, CN levels reached 8400, 7000, and 7150 particles $\mathrm{cm}^{-3}$, respectively. Linear regression of $\mathrm{CN}$ versus $C O$ yielded an $R^{2}=0.74$ and slope $=5.69$ (counts $\mathrm{cm}^{-3}$ ) $\mathrm{ppbv}^{-1}$ at $\mathrm{MWO}$, an $R^{2}=0.91$ and slope $=$ 5.59 (counts $\mathrm{cm}^{-3}$ ) $\mathrm{ppbv}^{-1}$ at CS, and an $R^{2}=0.61$ and slope $=3.63$ (counts $\mathrm{cm}^{-3}$ ) $\mathrm{ppbv}^{-1}$ at TF (excluding the last hours of the event). CN levels were above the 2-year 95th, 85th, and 50th percentile at MWO, CS, and TF, respectively.

[20] Aerosol scattering and hourly $\mathrm{PM}_{2.5}$ mass were measured only at TF (Figure 8c). The aerosol scattering coefficient was significantly elevated; the maximum value of this event, at $405 \mathrm{Mm}^{-1}$, exceeded the 99th percentile of the TF continuous 1.5-year data set for this site. Scattering was positively correlated with $\mathrm{CO}$, with $R^{2}=0.99$ and slope $=$ $0.68 \mathrm{Mm}^{-1} \mathrm{ppbv}^{-1}$. $\mathrm{PM}_{2.5}$ mass was also extremely high, reaching the largest value observed to date at TF, $338 \mu \mathrm{g} \mathrm{m}^{-3}$. Hourly averaged $\mathrm{PM}_{2.5}$ mass and $\mathrm{CO}$ were positively correlated $\left(R^{2}=0.77\right.$ and slope $=0.013\left(\mu \mathrm{g} \mathrm{m}^{-3}\right.$ $\left.\mathrm{ppbv}^{-1}\right)$. The similarity in timing of the enhancements in the continuous measurements of aerosol scattering and mass and $\mathrm{CO}$, described by the strong positive correlations, lends

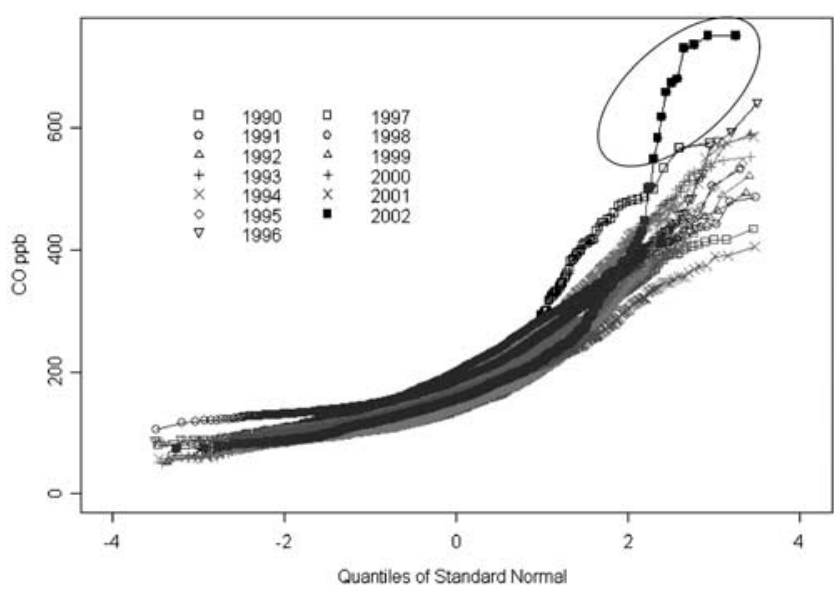

Figure 6. Standard normal quantile plot of summer daytime data for HFEMS is shown. The samples from the Quebec 2002 fires (shown inside the circle) clearly stand out as extreme compared to the past 12 summers. 
a) MWO

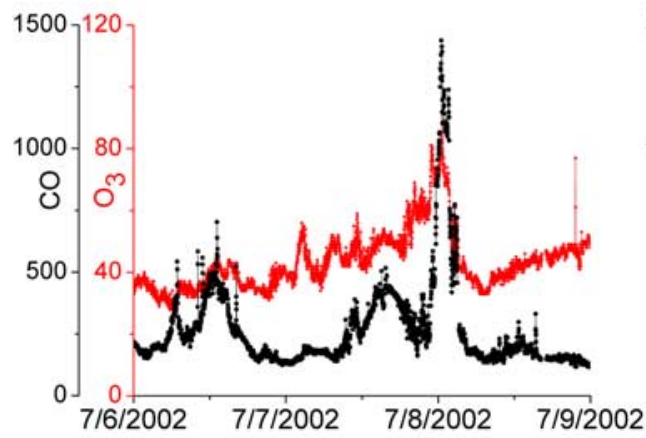

b) CS

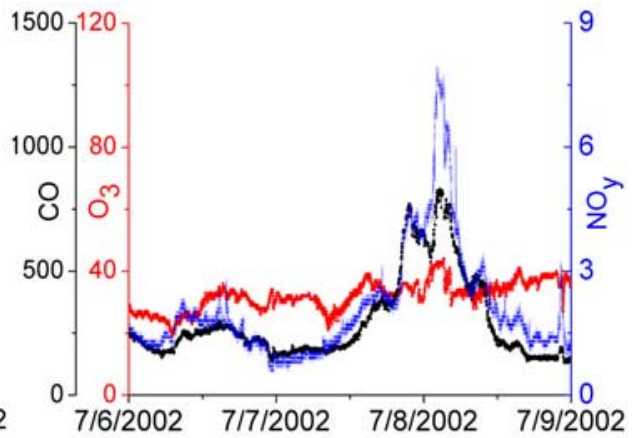

c) HFEMS

d) TF

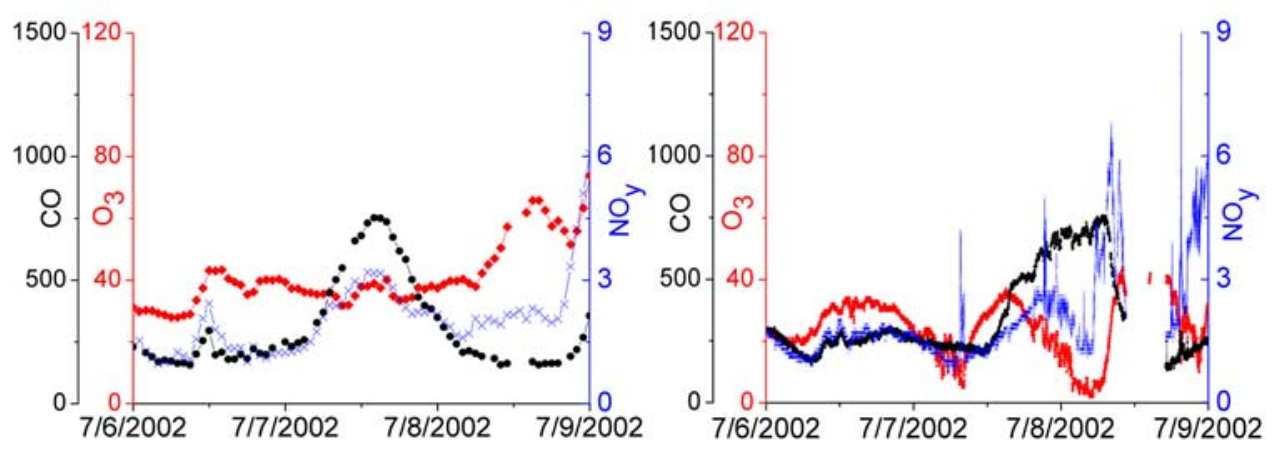

Figure 7. Enhancements in $\mathrm{O}_{3}$ and $\mathrm{NO}_{y}$ showed a clear altitudinal and latitudinal gradient. Both mixing ratios and $R^{2}$ values were greatest at $\mathrm{MWO}$ and lowest at TF. $\mathrm{CO}, \mathrm{O}_{3}$, and $\mathrm{NO}_{y}$ are all displayed in units of ppbv, and dates are given in LT with ticks at 0000 .

credence to the assumption that both the high aerosol loadings and the $\mathrm{CO}$ were associated with the smoke plume.

[21] Excess aerosol $\mathrm{K}$ (that fraction of total $\mathrm{K}$ not attributable to dust or salt) is a good tracer of biomass burning [Andreae, 1983]. Volatilization and reactions of $\mathrm{K}$ and $\mathrm{Cl}$ in vegetation [Liu et al., 2000] during burning leads to nucleation and condensation of potassium salt particles [Gaudichet et al., 1995]. Bulk water-soluble $\mathrm{K}^{+}$was elevated on the aerosol filter samples collected at CS between 7 July 1300 and 8 July 1200 LT and at MWO between 7 July 0900 and 8 July 0900 LT. The samples from both sites had the highest $\mathrm{K}^{+}$mixing ratios observed since AIRMAP began making measurements. Peak $\mathrm{K}^{+}$mixing ratios were comparable with 24-hour averages of 187 pptv at CS and 211 pptv at MWO (Table 1). A sample was not available from TF.

[22] With the exception of $\mathrm{SO}_{4}^{2-}$, all the aerosol-associated ions were significantly elevated at one or both sites (Table 1). In addition, there were significant differences between the two sites. At $\mathrm{MWO}, \mathrm{NO}_{3}^{-}$mixing ratios were twofold, and $\mathrm{NH}_{4}^{+}$mixing ratios were nearly 1.5 -fold higher than those observed at $\mathrm{CS}$. $\mathrm{Ca}^{2+}$ was 3 times higher, and $\mathrm{Mg}^{2+}$ was twice as high at CS compared to MWO. CS also had slightly higher $\mathrm{SO}_{4}^{2-}$ mixing ratios compared to MWO. Oxalate $\left(\mathrm{C}_{2} \mathrm{O}_{4}^{2-}\right)$ mixing ratios were quite high at both stations and were comparable. The presence of high mixing ratios of oxalate indicates that at least a portion of the organic aerosol in the smoke plume was water-soluble.

[23] Charge balance was not achieved for the ionic species measured, with cations significantly more abundant than anions (excess positive charge was 422 nanoequiva- lents at $\mathrm{CS}$ and 124 at $\mathrm{MWO}$ ). This result indicates that unmeasured anions, such as $\mathrm{CO}_{3}^{2-}, \mathrm{PO}_{4}^{3-}$, or other organics, were probably present in significant quantities in the aerosol. The presence of organic anions would be consistent with previous studies of biomass burning plumes [ $\mathrm{Li}$ et al., 2003]. While our ion chromatography (IC) system was not configured to quantify carboxylates in these samples, it is worth noting that the monocarboxylates peak in the chromatograms were significantly higher than in samples from surrounding days. We previously have found high mixing ratios of formic and acetic acids in Canadian biomass burning plumes [Lefer et al., 1994; Dibb et al., 1996].

\section{Discussion}

\subsection{Regional Picture}

\subsubsection{Carbon Monoxide}

[24] Enhanced CO mixing ratios were seen in the United States from Maine down to northern Virginia on 7-8 July 2002. The timing of the event, in terms of the maximum CO value, showed distinct regional patterns consistent with the observed presence of the plume (Figure 2). Maximum values at all stations occurred between 1400 LT 7 July (at HFEMS) and 1200 LT 8 July (at Acadia, Maine). Both the timing and the magnitude of the maximum value were impacted by whether or not the site was located in an urban area. Maximum hourly $\mathrm{CO}$ mixing ratios ranged from $738 \mathrm{ppbv}$ at TF to $3600 \mathrm{ppbv}$ in Washington, D. C. (Figure 9).

[25] Most sites can be sorted into one of three groups on the basis of the timing of the maximum $\mathrm{CO}$ value: group 1 with a maximum between 2000 and 2200 on 7 July, group 2 
a) MWO

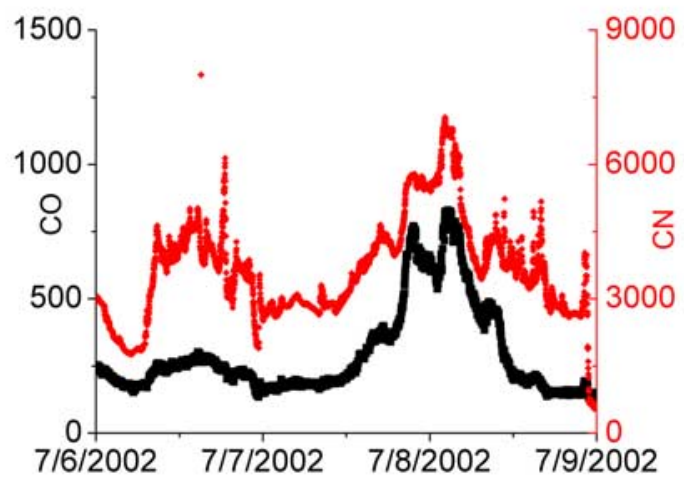

b) CS

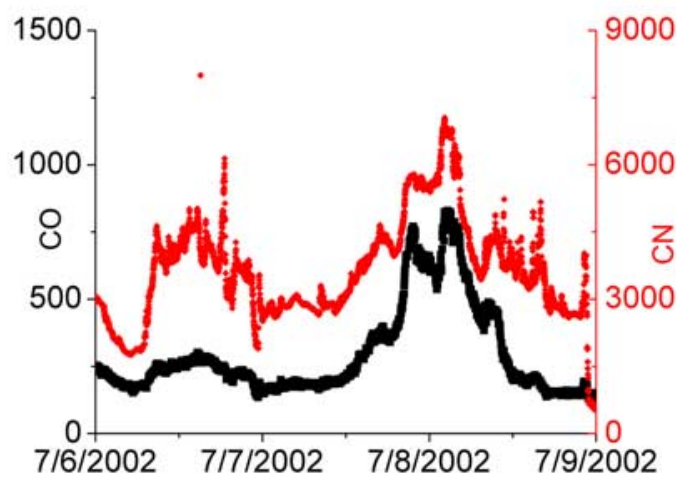

c) TF

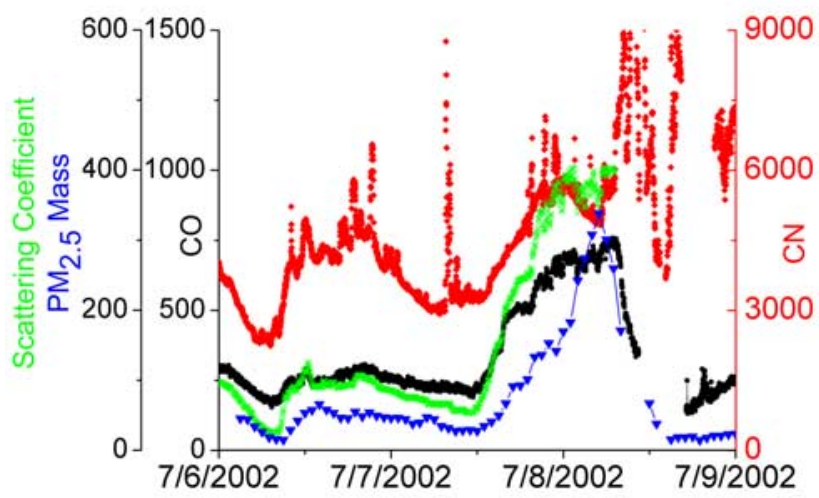

Figure 8. $\mathrm{CN}$ counts, $\mathrm{PM}_{2.5}$ mass, and aerosol scattering coefficients were all significantly enhanced and correlated with $\mathrm{CO}$ during the event. $\mathrm{CO}$ is shown in ppbv, $\mathrm{CN}$ is in counts $\mathrm{cm}^{-3}$, scattering coefficients are in $\mathrm{Mm}^{-1}$, and $\mathrm{PM}_{2.5}$ mass is in $\mu \mathrm{g} \mathrm{m}^{-3}$; dates are given in LT with ticks at 0000 .

with a maximum of $0500-0800$ on 8 July, and group 3 with a maximum of $1100-1200$ on 8 July (Figure 9). The similarity in timing of the $\mathrm{CO}$ peaks amongst these groups more firmly establishes the geographical extent of the plume in the absence of more precise biomass burning tracers at the majority of the monitoring stations. The sites in Maine saw the latest maximum $\mathrm{CO}$ values and fell into group 3 . Most of the low-altitude New England sites and the more western sites fell into group 1. Most of the sites in the urbanized eastern seaboard (New York City to Washington, D. C.) were in group 2. All the sites, except TF and the higher elevation sites HFEMS, MWO, and CS, clearly fell into one of these three groups.

[26] The timing of the event at the group 3 sites is explained by the south-to-southeastward shifts in the transport path of the smoke plume from 7 July to 9 July (Figure 3). The time series of several representative sites from each group helps to explain the variation in timing between sites in groups 1 and 2 (Figure 10). All sites in groups 1 and 2 exhibited a double peak structure in their time series, with the first peak occurring between 2000 and 2200 LT 7 July and the second one occurring between 0500 and 0800 LT 8 July. In the cases where the maximum value occurred during the first peak (see the group 1 site, western Pennsylvania, in Figure 10), the mixing ratios in the second peak were only a little lower. When the maximum mixing ratios occurred in the morning of 8 July (see the group 2 site, Washington, D. C., in Figure 10), it was always significantly higher than the preceding nighttime peak. It is presumed that this was due to the Quebec plume mixing with local traffic emissions associated with Monday morning rush hour, resulting in very enhanced $\mathrm{CO}$ mixing ratios at the group 2 sites. TF was somewhat anomalous compared to other low-elevation rural sites in that the maximum occurred Monday morning as in group 2. Since the peak mixing ratio was not notably higher than the late 7 July enhancement, TF was determined to be more consistent with group 1 and is included in that group.

\subsubsection{Aerosol Chemistry}

[27] Elevated levels of fine $(<2.5-\mu \mathrm{m})$ aerosol elemental $\mathrm{K}, \mathrm{BC}$, and $\mathrm{OC}$ were present at IMPROVE stations across much of the east coast on 7 July. A distinct regional pattern was present (Figures 11a, 11b, and 11c) with the highest concentrations occurring directly under the plume as pictured in the GOES image (Figure 2a). Fine elemental $\mathrm{K}$ ranged from 0.013 to $0.91 \mathrm{\mu g} \mathrm{m}^{-3}$, BC ranged from 0.062 to $4.7 \mathrm{\mu g} \mathrm{m}^{-3}$, and OC ranged from 0.47 to $56.0 \mu \mathrm{g} \mathrm{m}^{-3}$ across the eastern seaboard. Lye Brook, Vermont; Brigantine, New York; and Washington, D. C., were the three long-term ( $>10$-year records) sites most affected by the plume. The samples from 7 July at Lye Brook and Brigantine both had the maximum $\mathrm{K}, \mathrm{BC}$, and $\mathrm{OC}$ concentrations ever observed at those sites. The sample from Washington,

Table 1. Mixing Ratios and Station-Specific Summary Statistics for MWO and CS Aerosol Samples ${ }^{\mathrm{a}}$

\begin{tabular}{lccccccc}
\hline Sample or Statistic & $\mathrm{K}^{+}$ & $\mathrm{NO}_{3}^{-}$ & $\mathrm{NH}_{4}^{+}$ & $\mathrm{SO}_{4}^{=}$ & $\mathrm{Ca}^{2+}$ & $\mathrm{Mg}^{2+}$ & $\mathrm{C}_{2} \mathrm{O}_{4}^{=}$ \\
\hline CS 7 July & 187 & 292 & 903 & 264 & 201 & 40 & 165 \\
CS 50th & 19 & 71 & 580 & 352 & 30 & 14 & \\
CS 75th & 28 & 180 & 1,095 & 638 & 58 & 27 & \\
CS 85th & 35 & 289 & 1,613 & 956 & 81 & 39 & \\
CS 95th & 47 & 571 & 2,761 & 1,776 & 129 & 74 & \\
CS maximum & 187 & 1,834 & 6,109 & 4,754 & 494 & 203 & \\
MWO 7 July & 211 & 665 & 1,217 & 227 & 67 & 21 & 180 \\
MWO 50th & 3.4 & 12 & 169 & 88 & 5 & 2 & \\
MWO 75th & 8 & 55 & 461 & 228 & 16 & 5 & \\
MWO 85th & 12 & 100 & 714 & 384 & 30 & 9 & \\
MWO 95th & 22 & 256 & 1,387 & 870 & 60 & 20 & \\
MWO maximum & 211 & 1,767 & 12,680 & 9,682 & 390 & 98 &
\end{tabular}

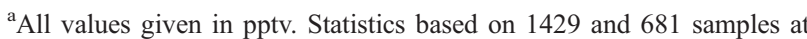
MWO and CS, respectively. 


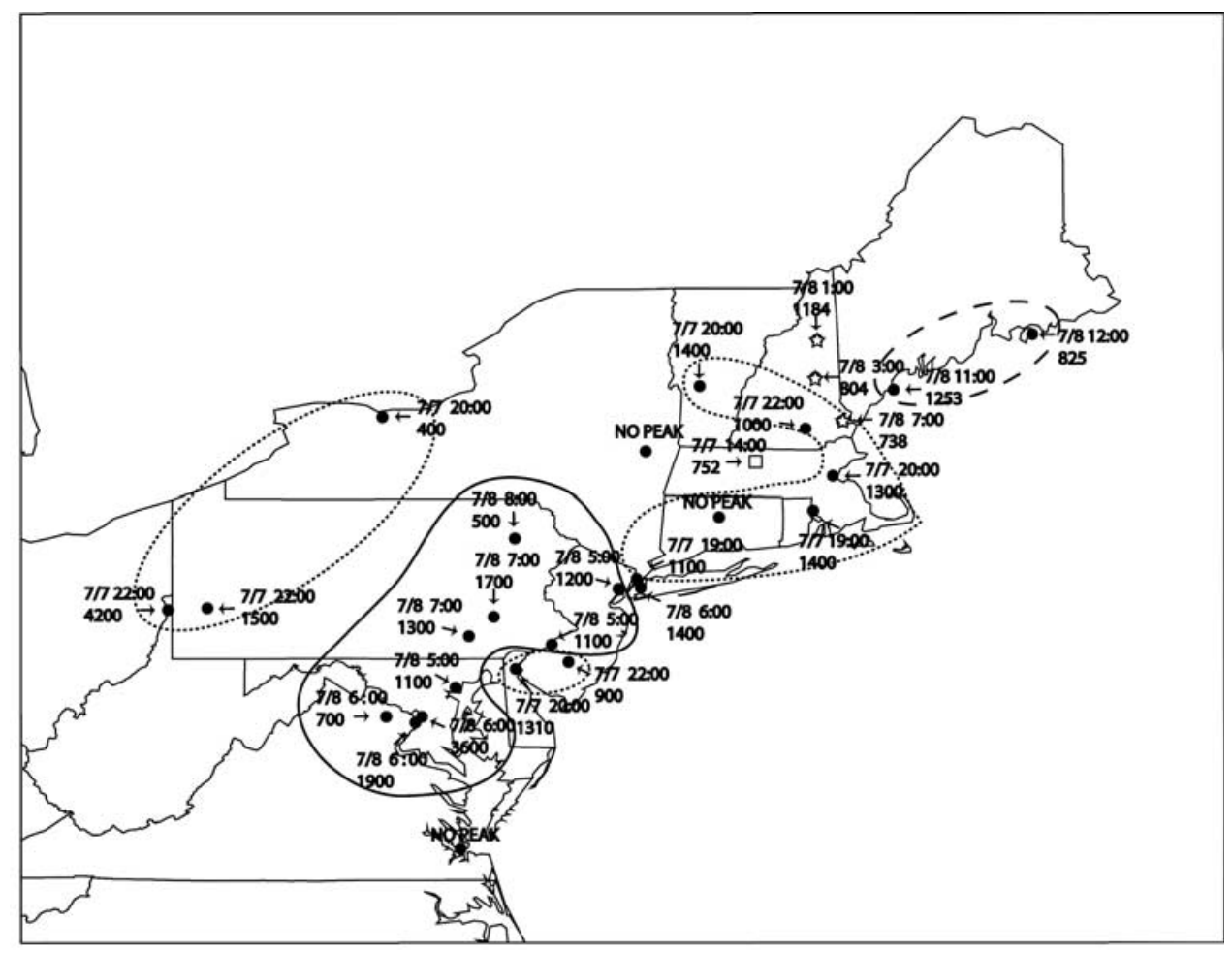

Figure 9. Map shows the timing and magnitude of the maximum CO mixing ratios. Group 1 is shown with a dotted line, group 2 is shown with a solid line, and group 3 is shown with a dashed line. Group 1 has a maximum between 2000 and 2200 UT at 7 July, group 2 has a maximum between 0500 and 0800 UT 8 July, and group 3 has a maximum between 1100 and 1200 UT 8 July. All times are given in LT.

D. C., had K concentrations above the 99th percentile (99th percentile $=0.30 \mu \mathrm{g} \mathrm{m}^{-3}$ ), BC levels below the median (median $=1.08 \mu \mathrm{g} \mathrm{m} \mathrm{m}^{-3}$ ), and the maximum $\mathrm{OC}$ concentration $\left(17.5 \mu \mathrm{g} \mathrm{m}^{-3}\right)$ observed at the site to date. At the most affected sites (total aerosol mass $>50 \mu \mathrm{g} \mathrm{m}^{-3}$, corresponding to those shown in red and orange on Figure 11a), comparison of the $\mathrm{PM}_{10}$ to the $\mathrm{PM}_{2.5}$ mass measurements suggested that $<5 \%$ of the total mass was in the coarse mode.

\subsubsection{Event Magnitude}

[28] The CO mixing ratios observed during this event at HFEMS confirmed that this was the most intense combustion plume, natural or anthropogenic, to affect this site during the summer in over a decade (Figure 6). At the four rural research sites, maximum $\mathrm{CO}$ mixing ratios represented 525-1025 ppbv enhancements above low mixing ratio conditions on surrounding days (Figure 7). In addition, aerosol $\mathrm{K}$ concentrations suggested that this was the most intense biomass burning plume sampled by the IMPROVE network on the east coast in at least the last decade. The magnitude of the impacts on atmospheric composition in the eastern United States is consistent with the anomalously large area burned in Quebec and the geographical extent of the plume observed from spaceborne instruments.

[29] Perhaps the most significant impact of this event was the reduced visibility due to the extremely high aerosol mass loadings and associated scattering effects (Figure 8). A reddish brown haze was clearly visible to the human eye throughout the New England region. Fine mass loadings exceeded the national ambient air quality standard
(NAAQS) at the four most impacted IMPROVE sites (sites shown in red in Figure 11c), indicating unhealthy conditions for all people. Neither $\mathrm{O}_{3}$ nor $\mathrm{CO}$ levels exceeded NAAQS standards at any sites and were considered healthy for all people.

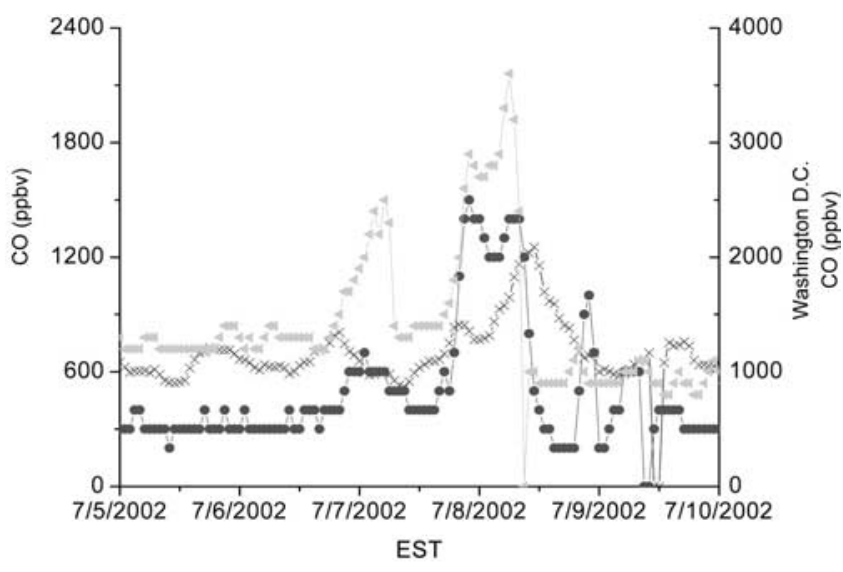

Figure 10. Time series of $\mathrm{CO}$ mixing ratios at EPA stations representative of groups $1-3$ shows the differences in the event in terms of timing and magnitude. The site in western Pennsylvania (dots) is representative of group 1; Washington, D. C., (sideways triangles) is representative of group 2; and Cape Elizabeth, Maine, (crosses) is representative of group 3 . 
a)

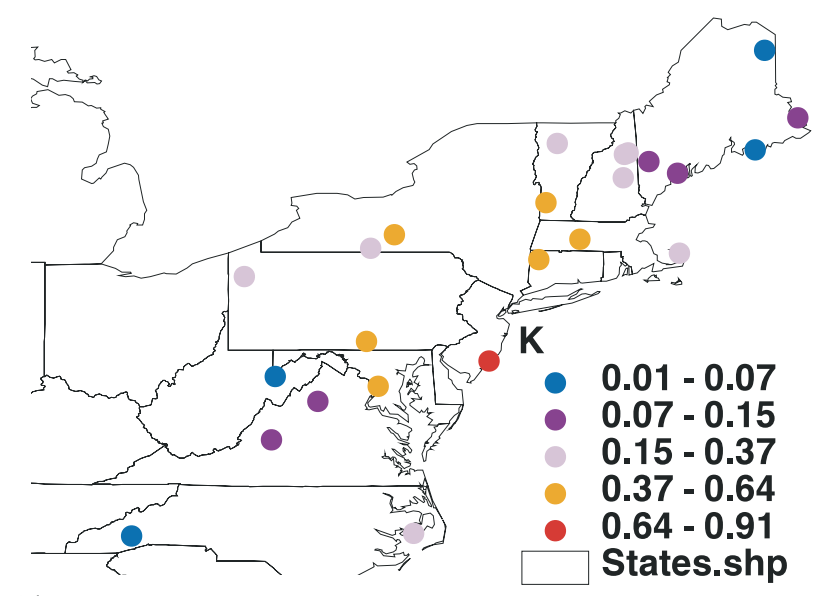

b)

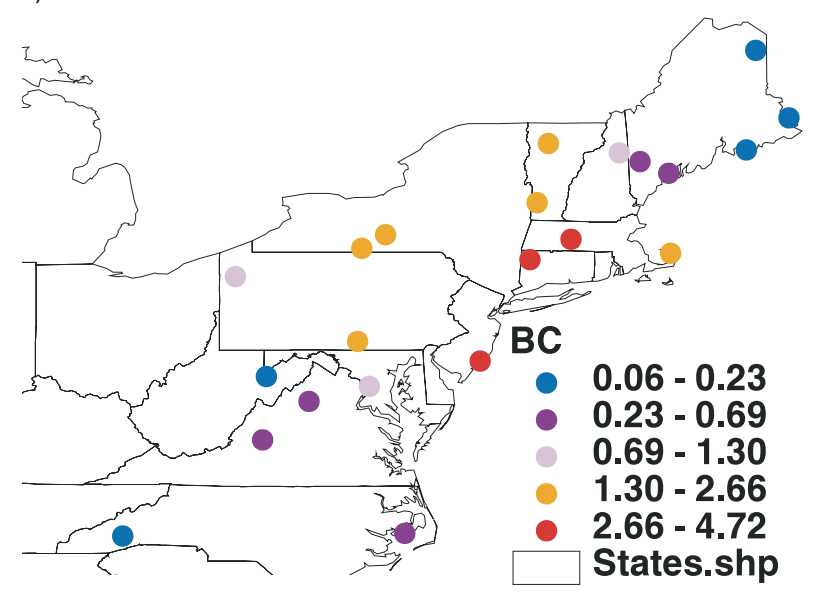

c)

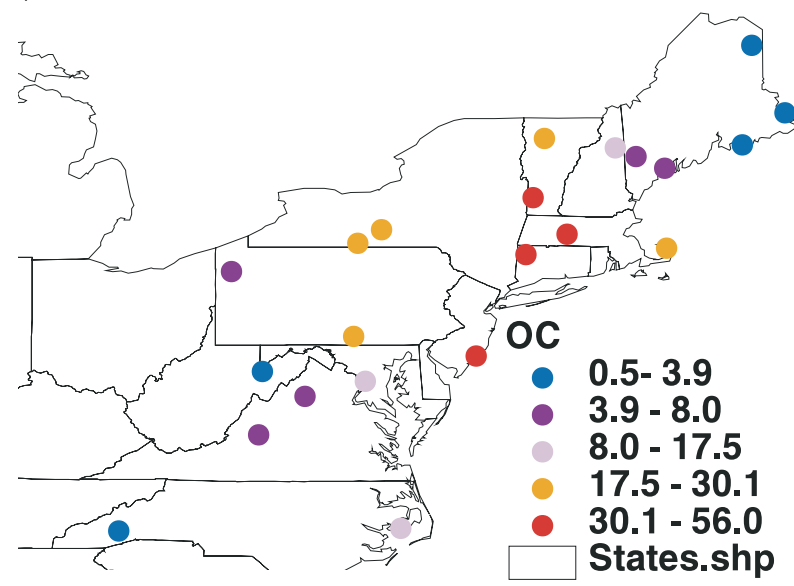

Figure 11. Fine aerosol at IMPROVE stations on 7 July for (a) elemental K, (b) black carbon, and (c) organic carbon is shown. Bulk $\mathrm{K}^{+}$concentrations at the AIRMAP stations MWO and CS are also displayed. The distinct regional pattern in all three aerosol types is indicative of the transport path of the smoke plume and consistent with remote sensing images from the same day. The shapes of the states are outlined (States.shp).
[30] The scattering coefficients at TF were extremely high for a rural New England site. All observations suggest that OC and/or nitrate aerosol likely dominated the scattering of light during this event, which is unusual for the northeast, where sulfate aerosol is typically dominant [Malm et al., 1994]. CN levels were also high and represented significant enhancements compared to conditions typical for CS and MWO (8400 and $7000 \mathrm{~cm}^{-3}$ versus median values of 1210 and $3350 \mathrm{~cm}^{-3}$ ). In addition, the fine aerosol mass loadings at TF during this event were even higher than the pollution haze events that intermittently impact the site; the peak hourly $\mathrm{PM}_{2.5}$ mass concentration during this event, $338 \mu \mathrm{g} \mathrm{m}^{-3}$, was over sixfold higher than the 95th percentile of $55 \mathrm{\mu g} \mathrm{m}^{-3}$.

[31] The peak $\mathrm{PM}_{2.5}$ mass concentrations in the Quebec plume were comparable to the airborne bulk mass particle concentrations measured in Brazil during the local biomass burning season (Table 2) [Artaxo et al., 1993]. The samples in Brazil were collected to be representative of the regional impact of biomass burning plumes. Additionally, $\mathrm{CN}$ levels at all AIRMAP stations were higher than the range observed during the Experiment for Regional Sources and Sinks of Oxidants in the heavily biomass burning impacted savanna region of central Africa (Table 2) [Ruellan et al., 1999]. These comparisons suggest that the regional aerosol loadings from this boreal forest fire were at least comparable to those observed in tropical regions during the local biomass burning season.

\subsection{Effects of Transport on Chemical Composition}

[32] Three key transport processes, transport height, dilution, and effective emission height, had significant impacts on the observed chemical characteristics of the smoke plume. The fire event consisted of numerous individual fires that likely had different emission ratios and effective emission heights depending on specific fire conditions. Individual fire characteristics were muted as the plumes converged and coalesced into a large regional plume. The only observation to point toward the preservation of different emission ratios between the sampled plumes was the disparity in absolute and relative $\mathrm{Ca}^{2+}$ and $\mathrm{Mg}^{2+}$ mixing ratios between $\mathrm{MWO}$ and $\mathrm{CS}$. While the increased absolute and relative mixing ratios of the soil tracers at CS could indicate differences in emission ratios, they may also simply indicate the presence of local dust at CS. All other observed site-to-site variation, including the observed altitudinal and latitudinal gradients in relative and absolute mixing ratios of $\mathrm{CO}, \mathrm{O}_{3}, \mathrm{NO}_{y}, \mathrm{NO}_{3}^{-}, \mathrm{NH}_{4}^{+}$, and $\mathrm{SO}_{4}^{2-}$, can largely be attributed to dilution and the

Table 2. Aerosol Physical and Optical Properties of Biomass Burning Plumes

\begin{tabular}{lccc}
\hline \multicolumn{1}{c}{ Location } & $\begin{array}{c}\mathrm{CN}, \\
\text { counts } \\
\mathrm{cm}^{-3}\end{array}$ & $\begin{array}{c}\text { Mass, } \\
\mathrm{g} \mathrm{m}^{-3}\end{array}$ & Reference \\
\hline AIRMAP MWO & 8400 & & this work \\
AIRMAP CS & 7000 & & this work \\
AIRMAP TF & 7150 & 338 & this work \\
Africa & $500-6000$ & & Ruellan et al. [1999] \\
Brazil $^{\text {b }}$ & & 300 & Artaxo et al. [1993]
\end{tabular}

${ }^{a}$ Aerosol particles with diameters $<2.5 \mu \mathrm{m}$.

${ }^{\mathrm{b}}$ Bulk (aerosol collected with no size cut). 
differential transformation processes related to sampling station altitude and corresponding transport height. The observed effects of dilution and transport height included changes in intensity, surfaces losses, and entrainment of polluted air masses, which will be discussed individually in sections 5.2.1, 5.2.2, and 5.2.3.

\subsubsection{Dilution}

[33] The intensity of the smoke plume diminished as it traveled farther south, at least at the New England sites. Carbon monoxide mixing ratios showed clear decreases from north to south, with a difference in peak mixing ratios of $\sim 680$ ppbv between MWO and TF. Comparing HFEMS and CS, which are at comparable altitudes, CS had higher $\mathrm{CO}$ mixing ratios with a difference in peak hourly averaged mixing ratios of $\sim 50 \mathrm{ppbv}$. As $\mathrm{CO}$ does not experience significant surface losses and is long-lived relative to plume transport time ( $\sim 2$ months in the summer at this latitude), the gradients in its mixing ratios clearly reflect changes in the intensity of the plume due to dilution with surrounding air.

\subsubsection{Effects of Surface Losses on Plume Chemistry}

[34] Studies of urban plumes have demonstrated that in photochemically aged plumes, $\mathrm{O}_{3}$ enhancements are positively correlated with $\mathrm{CO}$, indicating that the combustion products traced by $\mathrm{CO}$ are converted to $\mathrm{O}_{3}$ in the presence of photochemistry [Chin et al., 1994; Parrish et al., 1998]. Biomass burning plumes are subject to the same photochemical processes but often contain less reactive nitrogen and therefore exhibit a lower relative degree of enhancement in $\mathrm{O}_{3}$ as compared to anthropogenic combustion sources [Jacob et al., 1992; Mauzerall et al., 1996; Goode et al., 2000; Wotawa and Trainer, 2000]. Given that this event occurred during summer and given the estimated travel times, photochemical activity was likely. The correlation between $\mathrm{O}_{3}$ and $\mathrm{CO}$ can be used to examine the degree of $\mathrm{O}_{3}$ enhancement in the plume.

[35] During this event, there was a noticable relationship between sampling station altitude and $\mathrm{O}_{3}$ enhancements (Figure 7). The reduced or absent $\mathrm{O}_{3}$ enhancements at the lower altitude sites could be due to either enhanced depositional loss of $\mathrm{O}_{3}$ during transport or to lower $\mathrm{NO} / \mathrm{CO}$ emission ratios with associated reduction in the production of $\mathrm{O}_{3}$. Analysis of the EPA data included in this study supports the altitudinal and latitudinal gradients in $\mathrm{O}_{3}$ enhancement observed at the research sites. A positive correlation between $\mathrm{O}_{3}$ and $\mathrm{CO}$ was absent at all of the EPA stations (with the exception of Cadillac Mountain at $466 \mathrm{~m}$ in Acadia, Maine), even during the daylight hours of the event, suggesting little $\mathrm{O}_{3}$ enhancement in the plume. At Acadia, the only high-elevation EPA station included in this study, $\mathrm{O}_{3}$, reached $70 \mathrm{ppbv}$ and was positively correlated with CO $\left(R^{2}=0.57\right.$, slope $\left.=0.096 \mathrm{ppbv}^{\mathrm{ppbv}}{ }^{-1}\right)$.

[36] Instrumented aircraft sampled the plume over Maryland as part of the Regional Atmospheric Measurement, Modeling, and Prediction Program on 8 July around 1500 LT at $\sim 2.5-\mathrm{km}$ altitude [Taubman et al., 2004]. The plume observations above the inversion layer over Maryland on 8 July further strengthen and extend the observed gradient. The airborne samples showed $\mathrm{O}_{3}$ to be quite elevated and highly correlated with $\mathrm{CO}$. Ozone and $\mathrm{CO}$ mixing ratios peaked at $\sim 2.5 \mathrm{~km}$ above sea level, reaching 160 and 1555 ppbv, respectively. The correlation between
$\mathrm{O}_{3}$ and $\mathrm{CO}$ in the plume was quite remarkable, with an $R^{2}$ value of 0.92 and a slope of 0.062 . The $\mathrm{O}_{3}$ and $\mathrm{CO}$ enhancements were approximately 90 and $1350 \mathrm{ppbv}$ above mixing ratios in surrounding air masses above and below the plume of approximately 70 and 200 ppbv, respectively.

[37] The $\mathrm{O}_{3}$ enhancements at CS, at MWO, and aloft were in the range of previously reported values, 10$132 \mathrm{ppbv}$, for boreal forest fire plumes [Browell et al., 1994; Wotawa and Trainer, 2000; Goode et al., 2000]. However, the $\Delta \mathrm{O}_{3} / \Delta \mathrm{CO}$ ratio of 0.062 of this plume at $2.5 \mathrm{~km}$, determined by the slope of the linear correlation, was on the low end of those previously observed, and values at the New England research sites (0.014-0.028) were significantly lower than those previously observed. Reported $\Delta \mathrm{O}_{3} / \Delta \mathrm{CO}$ ratios for photochemically active boreal forest fire plumes encountered above the boundary layer over Alaska, eastern Canada, and the Midwest ranged from 0.04 to 0.2 [Jacob et al., 1992; Mauzerall et al., 1996; Goode et al., 2000; Wotawa and Trainer, 2000].

[38] In contrast, the $\Delta \mathrm{NO}_{y} / \Delta \mathrm{CO}$ ratios at HFEMS and TF (2.5 and 2.4 pptv ppbv $^{-1}$ ), were nearly comparable to, and those at CS were significantly higher (7.4 pptv ppbv $\left.{ }^{-1}\right)$ than, plumes sampled during Arctic Boundary Layer Expedition (ABLE 3A), which had enhanced $\mathrm{O}_{3}$ and $\Delta \mathrm{O}_{3} / \Delta C O$ ratios consistent with other boreal biomass burning plumes. The $\Delta \mathrm{NO}_{y} / \Delta \mathrm{CO}$ ratio for biomass burning plumes during ABLE 3A over Alaska ranged from 3.2 to $3.6 \mathrm{pptv}_{\mathrm{ppbv}}{ }^{-1}$ [Wofsy et al., 1992]. The presence of reactive nitrogen suggests that $\mathrm{O}_{3}$ production was likely unless light was unable to penetrate to the lower levels of the plume. It is unlikely that light was unable to penetrate the plume across the entire region sampled by the EPA network, so $\mathrm{O}_{3}$ production should have been observed minimally along the edges of the plume.

[39] Expected $\mathrm{O}_{3}$ mixing ratios at the maximum observed $\mathrm{CO}$ mixing ratios can be estimated from the simple linear relationship $\mathrm{O}_{3}=\mathrm{CO}\left(\mathrm{O}_{3} / \mathrm{CO}\right)+b$, where the ratio is in the typical range of boreal forest fire plumes, $0.4-0.6$, and the intercept is from the least squares fit to observations (41 and 30, at MWO and CS, respectively). At MWO the predicted values are 101 and 130 ppbv $\mathrm{O}_{3}$ (using 0.4 and 0.6 , respectively), while at $\mathrm{CS}$ they are 63 and 80 ppbv $\mathrm{O}_{3}$. These predicted mixing ratios would represent $\mathrm{O}_{3}$ enhancements in the range of $10-40$ ppbv above those actually observed. The $e$-folding lifetime of $\mathrm{O}_{3}$ in the plume would have been 1 week assuming only depositional loss, a mixing height of $3 \mathrm{~km}$ for the plume, and a 24-hour average dry deposition velocity of $0.5 \mathrm{~cm} \mathrm{~s}^{-1}$. Thus, on the conservative side, $\mathrm{O}_{3}$ deposition during the two days of transport can explain a loss on the order of $15-30$ ppbv. Assuming a lower mixing height of $1 \mathrm{~km}$ would put the $e$-folding lifetime on the order of 2 days and predict losses on the order of 25-50 ppbv. The combined calculations support a $\Delta \mathrm{O}_{3} / \Delta \mathrm{CO}$ ratio of $0.04-0.06$ for the plumes sampled at the surface sites, depending on the assumptions made. No one set of assumptions accurately supports the observations at both MWO and CS.

[40] Thus the plumes sampled at lower elevation likely experienced some combination of decreased $\mathrm{O}_{3}$ production as well as increased depositional loss of $\mathrm{O}_{3}$ compared to the plumes sampled at higher altitudes. Significant interaction with the surface layer is also suggested by $\mathrm{CO}_{2}$ measure- 
Table 3. Ratios of Enhanced Ions to $\mathrm{K}^{+}$Indicating Distinct Differences in Aerosol Chemical Composition Between MWO and CS

\begin{tabular}{lcccccc}
\hline & $\mathrm{NH}_{4}^{+} / \mathrm{K}^{+}$ & $\mathrm{Mg}^{2+} / \mathrm{K}^{+}$ & $\mathrm{Ca}^{2+} / \mathrm{K}^{+}$ & $\mathrm{NO}_{3}^{-} / \mathrm{K}^{+}$ & $\mathrm{SO}_{4}^{=} / \mathrm{K}^{+}$ & $\mathrm{C}_{2} \mathrm{O}_{4}^{=} / \mathrm{K}^{+}$ \\
\hline $\mathrm{CS}$ & 4.83 & 0.21 & 1.07 & 1.56 & 1.41 & 0.88 \\
$\mathrm{MWO}$ & 5.76 & 0.10 & 0.32 & 3.14 & 1.08 & 0.85 \\
\hline
\end{tabular}

ments made at TF and HFEMS. Carbon dioxide was neither enhanced nor correlated with $\mathrm{CO}$ at either site (data not shown). Because $\mathrm{CO}_{2}$ is the dominant gas emitted by fire, these results imply that the air mass has had sufficient contact with the surface layer for photosynthesis and respiration to obscure the $\Delta \mathrm{CO}_{2} / \Delta \mathrm{CO}$ correlation and $\mathrm{CO}_{2}$ enhancement introduced at the source.

[41] The distinct changes in aerosol composition between MWO and CS provide further evidence for surface losses, in this case, of $\mathrm{NO}_{y}$. The ratios of the other enhanced ions to $\mathrm{K}^{+}$indicate distinct differences in aerosol chemical composition between MWO and CS. MWO had significantly higher $\mathrm{NH}_{4}^{+} / \mathrm{K}^{+}$and $\mathrm{NO}_{3}^{-} / \mathrm{K}^{+}$ratios, significantly lower $\mathrm{Ca}^{2+} / \mathrm{K}^{+}$and $\mathrm{Mg}^{2+} / \mathrm{K}^{+}$, and slightly lower $\mathrm{SO}_{4}^{2-} / \mathrm{K}^{+}$ratios, compared to CS (Table 3). While $\mathrm{K}$ does not seem to be emitted in a constant ratio to other aerosol constituents [Artaxo et al., 1993; Gorzelska et al., 1994], the similarity in $\mathrm{K}$ and oxalate ratios between the sites would seem to indicate that the ratios are revealing differences related primarily to chemical evolution and depositional losses during transport rather than emission ratios.

[42] The increased absolute and relative mixing ratios of $\mathrm{NO}_{3}^{-}$and $\mathrm{NH}_{4}^{+}$observed at MWO indicate that this portion of the smoke plume likely experienced reduced depositional loss of those species or their precursors. $\mathrm{NO}_{x}$ and $\mathrm{NH}_{3}$ are both released from biomass burning [Lobert and Warnatz, 1993] and are then converted to aerosol $\mathrm{NO}_{3}^{-}$and $\mathrm{NH}_{4}^{+}$ through heterogeneous chemical reactions [Li et al., 2003; Goode et al., 2000; Nance et al., 1993]. It is unlikely that both $\mathrm{NO}_{x}$ and $\mathrm{NH}_{3}$ emissions were reduced, as they are the dominant products of flaming and smoldering combustion, respectively [Goode et al., 2000, and references therein; Lobert and Warnatz, 1993]. Thus the reduced $\mathrm{NO}_{3}^{-}$and $\mathrm{NH}_{4}^{+}$observed at CS must be due to enhanced depositional loss of $\mathrm{HNO}_{3}$ and $\mathrm{NH}_{3}$ and the resultant reduced production of $\mathrm{NO}_{3}^{-}$and $\mathrm{NH}_{4}^{+}$.

\subsubsection{Effects of Entrainment of Polluted Air Masses on Plume Aerosol Chemistry}

[43] Comparison of the chemical characteristics of the aerosol in this plume to those in prior events suggests that the long-range transport associated with this event resulted in significant alteration of the biomass burning aerosol through the incorporation of polluted air masses and the continued chemical evolution of the biomass burning emissions. The higher absolute and relative $\mathrm{SO}_{4}^{2-}$ mixing ratios at CS suggest entrainment of more polluted air masses compared to MWO, presumably due to enhanced interaction with the polluted boundary layer. The absence of detectable $\mathrm{Cl}^{-}$in our samples indicates nearly complete or complete conversion of $\mathrm{KCl}$, the dominant type of $\mathrm{K}$ salt in very young smoke, to potassium sulfate or nitrate, which is consistent with the suspected age of the plume of 1-2 days [Li et al., 2003]. This conversion process likely incorporated reactive gases from the biomass burning plume as well as the surrounding air mass, in particular, anthropogenic $\mathrm{SO}_{2}$ emissions.

[44] The significant entrainment of non-biomass burning inorganic aerosol is further supported by data from the IMPROVE network. At the most heavily influenced IMPROVE sites (total aerosol mass $>50 \mu \mathrm{g} \mathrm{m}^{-3}$, shown in red and orange on Figure 11a), OC, BC, and inorganic aerosol made up between 44 and 55, 3 and 6 , and 42 and $53 \%$ of the total mass, respectively. Previous results from Africa and Brazil indicated that inorganic aerosol made up between 10 and $25 \%$ of the total mass [Ferek et al., 1998; Haywood et al., 2003]. The biomass burning emissions in those cases were released into a comparatively unpolluted atmosphere, whereas here they are superimposed upon highly polluted east coast air masses. It is only because of the unique signature of the biomass burning emissions that they were distinguishable from anthropogenic pollution loadings.

\subsection{Aerosol Mass Ratio Consistency for Biomass Burning Plumes From Various Sources}

[45] The $\mathrm{BC} / \mathrm{OC}$ mass ratio at the most heavily influenced sites ranged from 0.07 to 0.14 with an average value of 0.08 . The data from the IMPROVE sites were comparable to those obtained from prescribed burns in the northwest United States, from African savanna fires and Brazilian cerrado, and from grass and forest fires, where $\mathrm{BC} / \mathrm{OC}$ ratios ranged from 0.05 to 0.15 [Haywood et al., 2003; Ferek et al., 1998; Ruellan et al., 1999; Martins et al., 1996], but lower than the $0.17-0.20 \mathrm{BC} / \mathrm{OC}$ observed in a very young smoke plume from a savanna fire in South Africa [Hobbs et al., 2003]. In the prior studies the lower ratios, near 0.08 , were found to be indicative of smoldering combustion, and higher values, near 0.12 , were indicative of flaming combustion [Ferek et al., 1998; Ruellan et al., 1999]. The similarity in BC/OC ratios between southern Africa and Brazil led Haywood et al. [2003] to conclude that this ratio is fairly invariant between regions; our results strengthen this conclusion and broaden the generalization to include boreal regions.

[46] The K/BC mass ratio in samples of the July 2002 plume at IMPROVE stations varied from 0.13 to 0.68 with an average of 0.26 . These data cover approximately the same range, $0.11-0.64$, observed in biomass burning plumes in Africa and Brazil [Hobbs et al., 2003; Ruellan et al., 1999; Yamasoe et al., 2000; Ferek et al., 1998; Maenhaut et al., 1996; Andreae et al., 1998]. These results suggest that while the relative amounts of $\mathrm{BC}, \mathrm{OC}$, and $\mathrm{K}$ were determined by emission ratios, the inorganic mass increased to a greater extent with long-range transport because of the incorporation of polluted air masses with higher inorganic aerosol loadings and possibly also to continued gas-to-particle conversion of inorganic gases in the smoke plume. However, this observation must be taken with caution, as the 24-hour samples might have captured aerosol not associated with the smoke plume.

[47] In summary, while transport height was probably the dominant factor controlling the chemical characterization of the plume, transport distance also may have played an important role in determining the observed mixing ratios. Therefore it would seem likely that during this event, transport height and the resultant degree of surface layer interaction was the dominant factor controlling more reac- 
tive species such as $\mathrm{NO}_{y}, \mathrm{O}_{3}, \mathrm{NO}_{3}^{-}, \mathrm{NH}_{4}^{+}$, and $\mathrm{SO}_{4}^{2-}$, and transport distance (i.e., dilution and mixing) was the dominant factor controlling more stable species such as CO.

\section{Conclusions}

[48] The smoke plume generated from the severe burning in Quebec in early July 2002 clearly had major impacts on air quality across the east coast of the United States, in both urban and rural areas. The combined data from the four networks all suggest that this was the largest and most intense biomass burning plume to impact the east coast in over a decade. The event was marked by significant enhancements in $\mathrm{CO}, \mathrm{PM}_{2.5}$ aerosol mass, organic and black carbon aerosols, and the soluble aerosol species $\mathrm{NO}_{3}^{-}, \mathrm{Ca}^{2+}$, oxalate, and the biomass burning tracer $\mathrm{K}^{+}$. In addition to the pollutants discussed here, significant gaseous mercury loadings were also found to be present in the smoke plume in samples colleted at HFEMS [Sigler et al., 2003]. The CO mixing ratios and aerosol mass loadings in the smoke plume were comparable to the most intense combustion pollution plumes and anthropogenic haze events to have ever impacted these rural New England sites.

[49] The degree of enhancement in $\mathrm{O}_{3}, \mathrm{NO}_{y}, \mathrm{NO}_{3}^{-}, \mathrm{NH}_{4}^{+}$, and $\mathrm{SO}_{4}^{2-}$ mixing ratios showed significant variation with sampling station elevation and latitude. The variation was likely due to a combination of factors related to the altitude of transport, which was shown to vary with sampling station elevation. The smoke plume reaching lower elevation sites clearly experienced enhanced interaction with the surface layer compared to higher sites because of subsiding transport along isentropic surfaces. Transport in the boundary layer likely resulted in increased depositional loss and increased incorporation of polluted air masses compared to transport in the free troposphere. The impact of varied emission ratios on the observed plume heterogeneity can not be assessed with the available data, but the emission ratios do not appear to be the dominant controlling factor. Decreased mixing ratios at more southerly sampling sites likely reflected increased dilution of the smoke plume as it dispersed over time and transport distance.

[50] While fires and the resultant smoke plumes of this magnitude are uncommon in the eastern United States, biomass burning can at times have a larger impact than anthropogenic sources on air quality in the heavily polluted east coast. Measurements indicated significant enhancements of many gas phase species; however, the most notable effect was the haze created by the very high aerosol loadings. This was one of the most intense haze events to impact TF, which is only $\sim 100 \mathrm{~km}$ downwind of Boston, in nearly 2 years of monitoring. Short-term regional haze from this plume was comparable to that observed in the tropics during the biomass burning season. Organic carbon aerosol likely dominated the very high scattering coefficients observed during this event.

[51] The chemical composition of the aerosol showed significant perturbation due to the long-range transport of the smoke plume. The significant increase in the inorganic fraction of the aerosol mass, compared to much younger smoke plumes, clearly pointed to additional gas to particle conversion of inorganic gases and/or the entrainment of polluted air masses, dominated by inorganic aerosol, during transport. The $\mathrm{BC} / \mathrm{OC}$ ratio in biomass burning aerosol appears to be fairly invariant between regions and fuel type and to be unaffected by long-range transport.

\section{Appendix A: AIRMAP Measurements}

\section{A1. Gas Phase Measurements}

[52] Ozone was measured using Thermo Environmental Instruments (Franklin, Massachusetts) model 49C-PS, which is based on UV photometric detection at $254 \mathrm{~nm}$. The limit of detection was $\sim 1.0$ ppbv. Carbon monoxide was measured with extensively modified Thermo Environmental Instruments model 48CTL [Parrish et al., 1994]. The technique uses a filter correlation method based on absorption of infrared radiation at $4.6 \mu \mathrm{m}$. Modifications to the instruments have improved stability significantly and added the capability to conduct frequent zeroing and standard addition calibrations. Zeroing was accomplished every 10 min by first passing ambient air through a catalyst of palladium on alumina heated to $250^{\circ} \mathrm{C}$. Calibration was conducted in ambient air by dynamically diluting a $\sim 5$-ppmv CO primary standard (Scott Marrin, Inc., $\pm 2 \%$ National Institute of Standards and Technology (NIST) certified) so as to add a spike of $\sim 300 \mathrm{ppbv}$. The limit of detection was $\sim 20 \mathrm{ppbv}$ and the precision $\pm 12 \%$.

[53] Total reactive nitrogen $\left(\mathrm{NO}_{y}=\mathrm{NO}+\mathrm{NO}_{2}+\mathrm{HNO}_{3}+\right.$ PAN + alkyl nitrates + aerosol $\left.\mathrm{NO}_{3}^{-}+\ldots\right)$ was measured using a custom-modified Thermo Environmental Instruments model $42 \mathrm{C}$. We used a molybdenum converter heated to $350 \pm 0.5^{\circ} \mathrm{C}$ to reduce $\mathrm{NO}_{y}$ compounds to $\mathrm{NO}$, which was subsequently measured by $\mathrm{NO}_{2}$ chemiluminescence. The inlet to the converter was a $10-\mathrm{cm}$ length of perfluoroalkoxy Teflon tubing heated to $50^{\circ} \mathrm{C}$. A test of the conversion efficiency of both $\mathrm{HNO}_{3}$ and $\mathrm{NH}_{3}$ was performed and found to be satisfactory. We found for $50 \mathrm{ppbv} \mathrm{HNO}_{3}, 100 \%$ conversion and for 1 ppmv $\mathrm{NH}_{3}$ a positive signal of only $\sim 100$ pptv $\mathrm{NO}_{y}$. In the field, conversion efficiency was checked daily by passing $\sim 25$ ppbv of isopropyl nitrate through the converter; during the period of this study, conversion efficiency was $104 \pm 6 \%$. This $\mathrm{NO}_{y}$ compound is relatively difficult to convert and is a good overall check on converter performance [Bradshaw et al., 1998]. An Aadco purifier provided air for zeroing and dilution of a $\sim 50$-ppbv NO standard (Scott Marrin, Inc., $\pm 2 \%$ NIST certified) to $\sim 10 \mathrm{ppbv}$ for calibration. Zeroing and calibration procedures were conducted every 12 hours.

[54] All instrument operations and data acquisition protocols are controlled automatically using National Instruments hardware and software. One-minute-averaged data are obtained from each site over the Internet every 15 min and displayed in near-real time on the AIRMAP web page (http:// www.airmap.unh.edu). We used the 1-min data in our analysis except when 1-hour averages were required for comparison to data from other sites or instruments. All standard gases used by the AIRMAP network are NIST traceable. All duplicate instruments in the AIRMAP network are run side by side and determined to be comparable when initially deployed to the field and after major maintenance and repair.

\section{A2. Aerosol Collection and Analysis}

[55] Bulk 24-hour (1200-1200 UT) aerosol samples were collected daily at CS and MWO, and field blanks were 
collected every 7 days. Bulk aerosols were collected on 90-mm Teflon filters (Fluropore filters, Millipore, Bedford, Massachusetts) using a custom manufactured sampling device mounted near the manifold inlet. The soluble ions in bulk aerosol samples were extracted from Teflon filters and analyzed by IC as described by DeBell et al. [2004]. $\mathrm{PM}_{2.5}$ (particle diameter $<2.5 \mu \mathrm{m}$ ) mass measurements were made using a Continuous Ambient Mass Monitor instrument (Thermo Anderson, Franklin, Massachusetts). CN measurements were made with a Thermo Systems Inc. (TSI) model 3022A (TSI Incorporated, St. Paul, Minnesota). Aerosol scattering coefficient measurements were made at $530 \mathrm{~nm}$ with a Radiance Research model M903 nephelometer (Radiance Research, Seattle, Washington). Details of the operation and maintenance of all continuous aerosol instruments are presented by Slater and Dibb [2004].

[56] Acknowledgments. We appreciate the efforts of those involved in the IMPROVE network for making such a valuable data set available to the research community. The authors gratefully acknowledge the NOAA Air Resources Laboratory (ARL) for the provision of the HY-SPLIT transport and dispersion model and/or READY Web site (http://www.arl. noaa.gov/ready.html) used in this publication. We would also like to thank Eric Hoffman and Jim Koermer of Plymouth State for providing meteorological figures. We would like to thank Steve Boles for generously offering his GIS capabilities. We also would like to thank Kevan Carpenter, Pieter Beckman, Sallie Whitlow, Karen Garrison, Don Troop, and Sean Wadsworth for their help in generating the data used in this work. This work was supported by the National Oceanic and Atmospheric Administration under grants NA17RP1488 and NA17RP2632. Measurements at Harvard Forest are supported by the Office of Science (BER), U.S. Department of Energy, through the Northeast Regional Center of the National Institute for Global Environmental Change under cooperative agreement DE-FC02-03ER63613, and the National Science Foundation Long-Term Ecological Research program.

\section{References}

Andreae, M. O. (1983), Soot carbon and excess fine potassium: Long-range transport of combustion-derived aerosols, Science, 220, 1148-1151.

Andreae, M. O., and P. Merlet (2001), Emission of trace gases and aerosols from biomass burning, Global Biogeochem. Cycles, 15, 955-966.

Andreae, M. O., et al. (1998), Airborne studies of aerosol emissions from savanna fires in southern Africa: 2. Aerosol chemical composition, J. Geophys. Res., 103, 32,119-32,128.

Artaxo, P., M. A. Yamasoe, J. V. Martins, S. Kocinas, S. Carvalho, and W. Maenhaut (1993), Case study of atmospheric measurements in Brazil: Aerosol emissions from Amazon basin fires, in Fire in the Environment: The Ecological, Atmospheric and Climatic Importance of Vegetation Fires, edited by P. J. Crutzen, pp. 139-158, John Wiley, Hoboken, N. J. Bradshaw, J., S. Sandholm, and R. Talbot (1998), An update on reactive odd-nitrogen measurements made during recent NASA Global Tropospheric Experiment programs, J. Geophys. Res., 103, 19,129-19,148.

Browell, E. V., M. A. Fenn, C. F. Butler, W. B. Grant, R. C. Harriss, and M. C. Shipham (1994), Ozone and aerosol distributions in the summertime troposphere over Canada, J. Geophys. Res., 99, 1739-1755.

Chin, M., D. J. Jacob, J. W. Munger, D. D. Parrish, and B. G. Doddridge (1994), Relationship of ozone and carbon monoxide over North America, J. Geophys. Res., 99, 14,565-14,573.

Cofer, W. R., III, E. L. Winstead, B. J. Stocks, L. W. Overbay, J. G Goldammer, D. R. Cahoon, and J. S. Levine (1996), Emissions from boreal forest fires: Are the atmospheric impacts underestimated?, in Biomass Burning and Global Change, edited by J. S. Levine, pp. 834-839, MIT Press, Cambridge, Mass.

Conard, S. G., and G. A. Ivanova (1997), Wildfire in Russian boreal forests: Potential impacts of fire regime characteristics on emissions and global carbon balance estimates, Environ. Pollut., 98, 305-313.

Cooper, O. R., J. L. Moody, T. D. Thornberry, M. S. Town, and M. A. Carroll (2001), PROPHET 1998 meteorological overview and air-mass classification, J. Geophys. Res., 106, 24,289-24,299.

Crutzen, P. J., and M. O. Andreae (1990), Biomass burning in the tropics: Impact on atmospheric chemistry and biogeochemical cycles, Science, 250, 1669-1678.

DeBell, L. J., M. Vozzella, R. W. Talbot, and J. E. Dibb (2004), Asian dust storm events of spring 2001 and associated pollutants observed in New
England by the Atmospheric Investigation, Regional Modeling, Analysis and Prediction (AIRMAP) monitoring network, J. Geophys. Res., 109, D01304, doi:10.1029/2003JD003733.

Dibb, J. E., R. W. Talbot, S. I. Whitlow, M. C. Shipham, J. Winterle, J. McConnel, and R. Bales (1996), Biomass burning signatures in the atmosphere and snow at Summit, Greenland: An event on 5 August 1994, Atmos. Environ., 30, 553-561.

Eldred, R. A., T. A. Cahill, K. Wilkinson, P. J. Feeney, J. C. Chow, and W. C. Malm (1990), Measurements of fine particles and their chemical components in the IMPROVE/NPS networks, in Visibility and Particles, vol. 17, edited by C. V. Mathai, pp. 187-196, Air and Waste Manage. Assoc., Pittsburgh, Pa.

Ferek, R. J., J. S. Reid, P. V. Hobbs, D. R. Blake, and C. Liousse (1998), Emission factors of hydrocarbons, halocarbons, trace gases, and particles from biomass burning in Brazil, J. Geophys. Res., 103, 32,107-32,118.

Forster, C., et al. (2001), Transport of boreal forest fire emissions from Canada to Europe, J. Geophys. Res., 106, 22,887-22,906.

Galanter, M., H. Levy II, and G. R. Carmichael (2000), Impacts of biomass burning on tropospheric $\mathrm{CO}, \mathrm{No}_{x}$, and $\mathrm{O}_{3}$, J. Geophys. Res., 105, 66336653.

Gaudichet, A., F. Echalar, B. Chatenet, J. P. Quisefit, G. Malingre, H. Cachier, P. Buatmenard, P. Artaxo, and W. Maenhaut (1995), Traceelements in tropical African savanna biomass burning aerosols, J. Atmos. Chem., 22, 19-39.

Goode, J. G., R. J. Yokelson, D. E. Ward, R. A. Susott, R. E. Babbitt, M. A. Davies, and W. M. Hao (2000), Measurements of excess $\mathrm{O}_{3}, \mathrm{CO}_{2}, \mathrm{CO}$, $\mathrm{CH}_{4}, \mathrm{C}_{2} \mathrm{H}_{4}, \mathrm{C}_{2} \mathrm{H}_{2}, \mathrm{HCN}, \mathrm{NO}, \mathrm{NH}_{3}, \mathrm{HCOOH}, \mathrm{CH}_{3} \mathrm{COOH}, \mathrm{HCHO}$, and $\mathrm{CH}_{3} \mathrm{OH}$ in 1997 Alaskan biomass burning plumes by airborne Fourier transform infrared spectroscopy (AFTIR), J. Geophys. Res., 105, $22,147-22,166$.

Gorzelska, K., R. W. Talbot, K. Klemm, B. Lefer, O. Klemm, G. L. Gregory, B. Anderson, and L. A. Barrie (1994), Chemical composition of the atmospheric aerosol in the troposphere over the Hudson Bay lowlands and Quebec-Labrador regions of Canada, J. Geophys. Res., 99, $1763-1779$.

Haywood, J. M., S. R. Osborne, P. N. Francis, A. Keil, P. Formenti, M. O. Andreae, and P. H. Kaye (2003), The mean physical and optical properties of regional haze dominated by biomass burning aerosol measured from the C-130 aircraft during SAFARI 2000, J. Geophys. Res., 108(D13), 8473, doi:10.1029/2002JD002226.

Hobbs, P. V., P. Sinha, R. J. Yokelson, T. J. Christian, D. R. Blake, S. Gao, T. W. Kirchstetter, T. Novakov, and P. Pilewskie (2003), Evolution of gases and particles from a savanna fire in South Africa, J. Geophys. Res., 108(D13), 8487, doi:10.1029/2002JD002325.

Intergovernmental Panel on Climate Change (IPCC) (2001), Climate Change 2001: The Scientific Basis, edited by J. T. Houghton et al., Cambridge Univ. Press, New York.

Jacob, D. J., et al. (1992), Summertime photochemistry of the troposphere at high northern latitudes, J. Geophys. Res., 97, 16,421-16,431.

Khalil, M. A. K., and R. A. Rasmussen (2003), Tracers of wood smoke, Atmos. Chem., 37, 1211-1222.

Lefer, B. L., et al. (1994), Enhancement of acidic gases in biomass burning impacted air masses over Canada, J. Geophys. Res., 99, 1721-1737.

Li, J., M. Pósfai, P. V. Hobbs, and P. R. Buseck (2003), Individual aerosol particles from biomass burning in southern Africa: 2. Compositions and aging of inorganic particles, J. Geophys. Res., 108(D13), 8484, doi:10.1029/2002JD002310.

Liu, X. D., P. Van Espen, F. Adams, J. Cafmeyer, and W. Maenhaut (2000), Biomass burning in southern Africa, individual particle characterization of atmospheric aerosols and savanna fire samples, J. Atmos. Chem., 36, $135-155$.

Lobert, J. M., and J. Warnatz (1993), Emissions from the combustion process in vegetation, in Fire in the Environment: The Ecological, Atmospheric and Climatic Importance of Vegetation Fires, edited by P. J. Crutzen and J. G. Goldammer, pp. 15-37, John Wiley, Hoboken, N. J.

Maenhaut, W., I. Salma, J. Cafmeyer, H. J. Annegarn, and M. O. Andreae (1996), Regional atmospheric aerosol composition and sources in the eastern Transvaal, South Africa, and impact of biomass burning, J. Geophys. Res., 101, 23,631-23,650.

Malm, W. C., J. F. Sisler, D. Huffman, R. A. Eldred, and T. A. Cahill (1994), Spatial and seasonal trends in particle concentration and optical extinction in the United States, J. Geophys. Res., 99, 1347-1370.

Malm, W. C., J. V. Molenar, R. A. Eldred, and J. F. Sisler (1996), Examining the relationship among atmospheric aerosols and light scattering and extinction in the Grand Canyon area, J. Geophys. Res., 101, 19,25119,265 .

Martins, J. V., P. Artaxo, P. V. Hobbs, C. Liousse, H. Cachier, Y. Kaufman, and A. Plana-Fattori (1996), Particle size distributions, elemental compositions, carbon measurements, and optical properties of smoke from biomass burning in the Pacific Northwest of the United States, in Biomass 
Burning and Global Change, edited by J. S. Levine, pp. 716-732, MIT Press, Cambridge, Mass.

Marufu, L., F. Dentener, J. Lelieveld, M. O. Andreae, and G. Helas (2000), Photochemistry of the African troposphere: Influence of biomass burning emissions, J. Geophys. Res., 105, 14,513-14,530.

Mauzerall, D. L., D. J. Jacop, S. M. Fan, J. D. Bradshaw, G. L. Gregory, G. W. Sachse, and D. R. Blake (1996), Origin of tropospheric ozone at remote high northern latitude in summer, J. Geophys. Res., 101, 4175-4188.

McKeen, S. A., G. Wotawa, D. D. Parrish, J. S. Holloway, M. P. Buhr, G. Hübler, F. C. Fehsenfeld, and J. F. Meagher (2002), Ozone production from Canadian wildfires during June and July of 1995, J. Geophys. Res., 107(D14), 4192, doi:10.1029/2001JD000697.

Munger, J. W., S. C. Wofsy, P. S. Bakwin, S.-M. Fan, M. L. Goulden, B. C. Daube, A. H. Goldstein, K. E. Moore, and R. Fitzjarrald (1996), Atmospheric deposition of reactive nitrogen oxides and ozone in a temperate deciduous forest and a subarctic woodland: 1 . Measurements and mechanisms, J. Geophys. Res., 101, 12,639-12,657.

Nance, J. D., P. V. Hobbs, L. F. Radke, and D. E. Ward (1993), Airborne measurements of gases and particles from an Alaskan wildfire, J. Geophys. Res., 98, 14,873-14,882.

Nichol, J. (1998), Smoke haze in Southeast Asia: A predictable recurrence, Atmos. Environ., 32, 2715-2716.

Novelli, P. C., et al. (1998), An internally consistent set of globally distributed atmospheric carbon monoxide mixing ratios developed using results from an intercomparison of measurements, J. Geophys. Res., 103, $19,285-19,293$

Parrish, D. D., J. S. Holloway, and F. C. Fehsenfeld (1994), Routine, continuous measurement of carbon monoxide with parts per billion precision, Environ. Sci. Technol., 28, 1615-1618.

Parrish, D. D., M. Trainer, J. S. Holloway, J. E. Yee, M. S. Warshawsky, F. C. Fehsenfeld, G. L. Forbes, and J. L. Moody (1998), Relationships between ozone and carbon monoxide at surface sites in the North Atlantic region, J. Geophys. Res., 103, 13,357-13,376.

Ruellan, S., H. Cachier, A. Gaudichet, P. Masclet, and J. P. Lacaux (1999), Airborne aerosols over central Africa during the experiment for regional sources and sinks of oxidants (EXPRESSO), J. Geophys. Res., 104, $30,673-30,690$

Sigler, J. M., X. Lee, and W. Munger (2003), Emissions and long-range transport of gaseous mercury from a large-scale Canadian boreal forest fire, Environ. Sci. Technol., 37, 4343-4347.

Slater, J. F., and J. E. Dibb (2004), Relationships between surface and column aerosol radiative properties and air mass transport at a rural New England site, J. Geophys. Res., 109, D01303, doi:10.1029/ 2003JD003406.

Taubman, B. F., L. T. Marufu, B. L. Vant-Hull, C. A. Piety, B. G. Doddridge, R. R. Dickerson, and Z. Li (2004), Smoke over haze: Aircraft observations of chemical and optical properties and the effects on heating rates and stability, J. Geophys. Res., 109, D02206, doi:10.1029/ 2003JD003898

Wofsy, S. C., et al. (1992), Atmospheric chemistry in the Arctic and subarctic: Influence of natural fires, industrial emissions, and stratospheric inputs, J. Geophys. Res., 97, 16,731-16,746.

Wotawa, G., and M. Trainer (2000), The influence of Canadian forest fires on pollutant concentrations in the United States, Science, 288, 324-328. Yamasoe, M. A., P. Artaxo, A. H. Miguel, and A. G. Allen (2000), Chemical composition of aerosol particles from direct emissions of vegetation fires in the Amazon Basin: Water-soluble species and trace elements, Atmos. Environ., 34, 1641-1653.

L. J. DeBell, CIRA, Colorado State University, 1375 Campus Delivery, Fort Collins, CO 80523, USA. (debell@cira.colostate.edu)

J. E. Dibb, E. V. Fischer, S. E. Frolking, and R. W. Talbot, Institute for the Study of Earth, Oceans, and Space, University of New Hampshire, Durham, NH 03824, USA. (jack.dibb@unh.edu; efischer@gust.sr.unh.edu; steve.frolking@unh.edu; robert.talbot@unh.edu)

J. W. Munger, Department of Earth and Planetary Sciences, Harvard University, Cambridge, MA 02138, USA. (jwm@io.harvard.edu) 